\section{Arqueologia da Arquitectura em Contexto Urbano: reflexões a partir de três exemplos da cidade de Braga, Portugal}

\section{Archaeology of Architecture in urban context: reflections from three examples of the city of Braga, Portugal}

Luis Fontes*

Sofia Catalão

Mafalda Alves

Unidade de Arqueología da Universidade do Minho

\begin{abstract}
Resumo
A Arqueologia Urbana afirmou-se, a partir da década de 60 do século XX, como uma área disciplinar imprescindível para a definição estratégica do desenvolvimento de qualquer cidade histórica. Actualmente, a Arqueologia da Arquitectura, pelo seu potencial instrumental e metodológico, vem demonstrando que poderá dar um contributo significativo para a renovação das problemáticas de estudo do urbanismo, tanto na área do registo e documentação do existente, como na área da interpretação da evolução histórica das cidades. Neste artigo apresenta-se a experiência do projecto de estudo arqueológico da cidade de Braga, coordenado pela Unidade de Arqueologia da Universidade do Minho, discutindo três exemplos de intervenções no espaço urbano que, em nossa opinião, se enquadram na área mais específica da Arqueologia da Arquitectura e demonstram a importância da sua aplicação.
\end{abstract}

Palavras chave: Cidade de Braga, Arqueologia Urbana, Urbanismo medieval e moderno, metodologias

\begin{abstract}
The urban archaeology was affirmed, since the 1960's, as an essential knowledge area for the strategic definition of the development of any historic city. At present, the Archaeology of Architecture, due to its instrumental and methodological potential, demonstrates that it may strongly help to renew the studies of the town planning, both in recording and documenting the standing material, and to interpretate the historical evolution of the cities. This article presents the experience of the project of archaeological study of the city of Braga, coordinated by the Archaeology Unit of the Minho's University, discussing three examples of interventions in the urban space that, in our opinion, are fitted in the most specific area of the Archaeology of Architecture and demonstrate the importance of its application.
\end{abstract}

Key words: City of Braga, Urban Archaeology, Medieval and Modern urbanism, methodologies.

\footnotetext{
*fontes@uaum.uminho.pt; sophiecatalao@gmail.com; mafaldasda@gmail.com
}

«(...) As cidades europeias são uma parte determinante [dos cenários físicos das vivências humanas], e a conservação do seu património material é necessária para não se perder uma grande quantidade de valores a que só podemos ter acesso por essa via: a identidade dos lugares onde vivemos, a estabilidade que dá realce e significado ao fluir das diferentes experiências de cada geração, a permanência de um 'centro' que não muda tão rapidamente como a periferia, onde possamos, por conseguinte, depositar e partilhar uma parte das memórias que são demasiado pesadas para serem transportadas por cada indivíduo.» (Benevolo 1995: 13)

\section{INTRODUÇÃO}

Tal como consagra o Código de Boas Práticas para a "Arqueologia e Planeamento Urbano", aprovado pelo Comité do Património Cultural do Conselho da Europa em Março de 2000, «(...) Archaeology complemented by written sources and iconography is the first, indispensable step in any urban strategy. Its goal is not merely to study the town's structure and evolution, but also to assess its social and cultural development. (...) Urban archaeology tells us how the town has developed throughout its history, and introduces concepts such as empty / full, inside / outside, rich / poor, monumental / vernacular, planned / spontaneous, dense / diffuse, etc., concepts shared by archaeologists, town planners, architects and developers. (...)» (Ballester 2001).

De facto, é hoje amplamente reconhecido que o património arqueológico e arquitectónico, enquanto recurso susceptível de valorizaçôes múltiplas, constitui uma mais-valia estratégica para qualquer país ou região que se queira desenvolver e afirmar como sociedade de conhecimento, recaindo sobre os arqueólogos uma responsabilidade acrescida.

Sobre esta problemática, em especial das implicaçōes da prática da Arqueologia Urbana na gestão do património edificado, existe abundante bibliografia. Para Portugal ver, entre outros, Martins (2010) e VV.AA. (1986, 1994, 2002, 2004 e 2006a). Confrontar com Report on the situation of Urban Archaeology in Europe, Strasbourg: Council of Europe Publishing, 1999, Rodríguez Temiño (2004) ou VV.AA. (2009a e 2010).

Por outro lado, na sua especificidade metodológica e instrumental, a Arqueologia da Arquitectura é reconhecida como uma especialidade que pode renovar os estudos da arqueologia urbana (Azkarate Galai-Olaun 2008:13; 


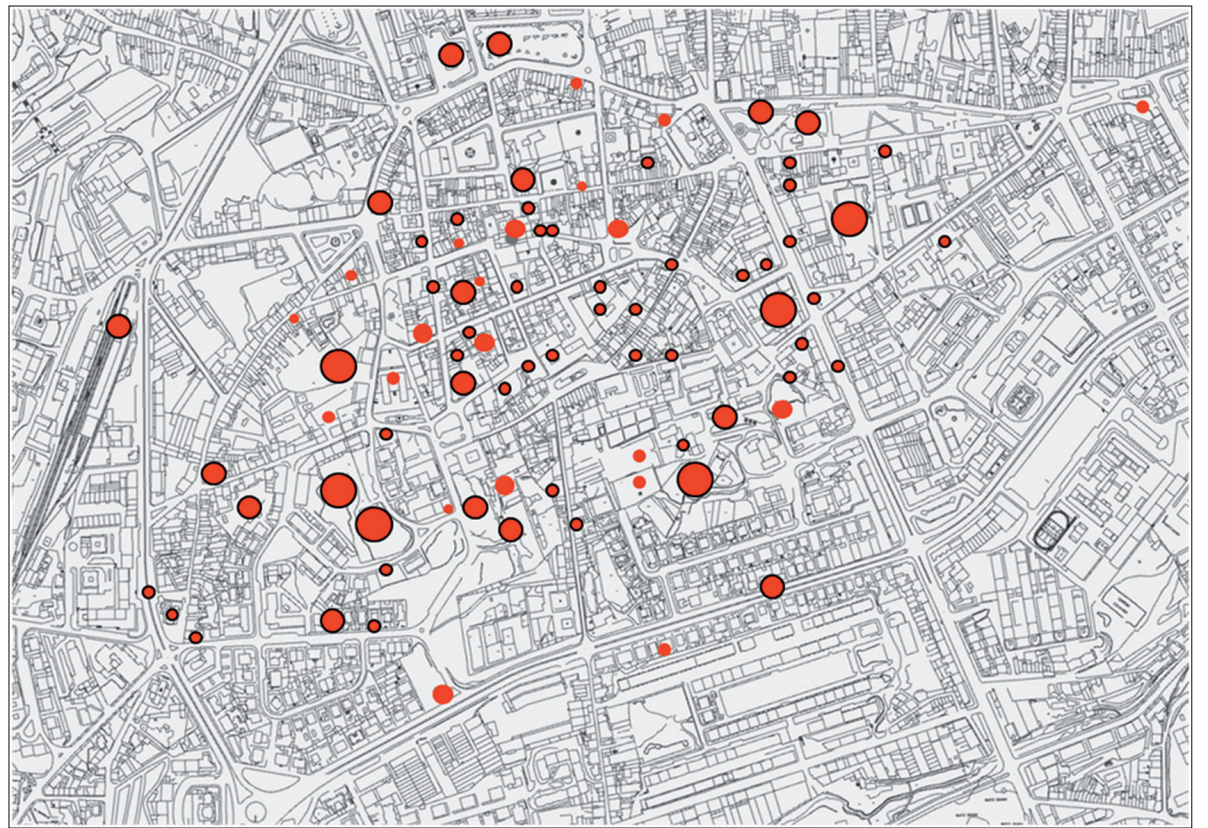

Fig. 1. Cartografia das intervenções arqueológicas realizadas pela UAUM em Braga
Mañana Borrazás, Blanco Rotea e Ayán Vila 2002:23), num momento tão mais importante quanto se assiste a um renovado interesse económico pela reocupação dos centros urbanos, com as entidades municipais a promoverem o desenvolvimento de programas integrados de recuperação dos centros históricos.

Importa assinalar que Braga foi a primeira cidade portuguesa a possuir um projecto de Arqueologia Urbana, iniciado em 1976, com a criação do Campo Arqueológico de Braga, destinado a fazer face aos impactes decorrentes da expansão da cidade sobre os terrenos onde se conservavam vestígios significativos da cidade romana de Bracara Augusta.

Essa responsabilidade foi directamente assumida pela Universidade do Minho que, em 1977, acompanhando as tendências europeias, reconheceu a importância da arqueologia para o estudo da cidade, criando a Unidade de Arqueologia, a quem foi cometida a responsabilidade de coordenar o "Projecto de Salvamento de Bracara Augusta». Desde então, a Unidade de Arqueologia da Universidade do Minho (UAUM) realizou, na área urbana de Braga e na sua periferia, largas dezenas de intervenções arqueológicas, quer de investigação, quer de natureza preventiva, tendo assumido a responsabilidade de estudar os seus resultados, propor a conservação de núcleos de ruínas de relevância patrimonial, contribuir para a sua valorização e promover a divulgação nacional e internacional do conhecimento obtido (consulte-se http://www.uaum.uminho.pt/).

Sobre a cidade romana de Bracara Augusta possui-se hoje um conhecimento significativo (Martins 2004; Mar- tins e Fontes 2010), conservando-se importantes núcleos de ruínas, já valorizados ou em via de o serem, destacandose, entre outros: as termas e o teatro do Alto da Cividade; parte significativa de um quarteirão da cidade romana, situado a oeste do Campo das Carvalheiras; as ruínas de uma casa romana e da muralha medieval, na cave da sede da junta de freguesia da Sé; as ruínas de várias edificações descobertas sob a catedral; a fonte/santuário rupestre da Fonte do Ídolo, na rua do Raio; a domus romana do Seminário de Santiago; o balneário pré-romano da Estação (Martins e Fontes 2007-2008:265-269).

Deve-se também à arqueologia o renovado conhecimento sobre a transição da cidade romana à cidade medieval, documentando-se a continuidade de ocupação da Bracara sueva e visigoda em todo o perímetro da sua muralha, consolidando-se as profundas alteraçôes do tecido urbano, iniciadas nos séculos IV-V com a desactivação dos grandes edifícios públicos romanos e com o desenvolvimento do novo centro cívico em torno da sede episcopal. Nos suburbia, surgem novos pólos de referência cristãos, com a construção de basílicas cemiteriais, como parecem confirmar os vestígios de necrópoles em São Victor e em São Vicente, ambas junto a eixos viários importantes que ligavam Braga ao interior galego (Fontes 2008:168; Martins e Fontes 2010:119; Fontes 2009:278-280).

É também nos arredores de Bracara que se constroem dois dos mais importantes mosteiros do Noroeste Peninsular - o de Dume, no século VI, por iniciativa de São Martinho (Fontes 2006), e o de São Salvador de Montélios, no século VII, por iniciativa de São Frutuoso (Fontes 
1989), ambos bispos de Braga e Dume. Ainda no século V, construiu-se no monte da Falperra ou de Santa Marta das Cortiças, antigo povoado fortificado sobranceiro à cidade de Braga, um amplo edifício áulico, com templo paleocristão anexo (Fontes 2008:171-173; Martins e Fontes 20072008:275-280).

Já no contexto da integração da cidade de Braga na órbita do reino asturiano-leonês, admite-se que à sua «restauração», no ano de 873 (Costa 1965:33), corresponda uma eventual reconstrução do perímetro defensivo, com redução significativa da área urbana. De facto, a reinterpretação de alguns dados arqueológicos, ainda que escassos, sugere que a cidade altomedieval foi cercada a sul por uma nova muralha, que se ligaria a noroeste e a sudeste ao troço setentrional da antiga cerca romana, que continuou a integrar a defesa da cidade (Fontes, Lemos e Cruz 1997-98:139; Marques 1986:7-9).

Da cidade pleno medieval de Braga possui-se igualmente um bom conhecimento, conservando-se praticamente quase toda a malha urbana da fase final desse período. Entre os núcleos de ruínas e valores arquitectónicos conservados e valorizados, destacam-se os que se relacionam com a cerca e o castelo que defendiam a cidade e com a sede episcopal: Torre de Menagem, Torre do postigo da Porta Nova, Torre de Santiago, Sé Catedral de Braga, Paço Episcopal e Largo da Praça Velha. Embora não acessíveis ao público, conservam-se troços da cerca medieval na Rua dos Biscainhos, na Rua do Anjo (no interior da cerca do Seminário de Santiago) e na Rua de São Marcos (Fontes 2004; Martins e Fontes 20072008:270-274).

A cidade moderna, apesar de beneficiar de importantes dados iconográficos, cartográficos e históricos é, do ponto de vista arqueológico, menos bem conhecida, reconhecendo-se que a nova abordagem da Arqueologia da Arquitectura possa acrescentar um novo conhecimento sobre a evolução da morfologia urbana e das arquitecturas modernas (Ribeiro 2008).

No artigo que a seguir se apresenta, pretende-se dar testemunho das práticas de Arqueologia da Arquitectura realizadas pela UAUM na cidade de Braga, apresentando três exemplos de intervenções que, embora distintas nas estratégias e modalidades de actuação, do ponto de vista da prática da Arqueologia Urbana (acções preventivas de acompanhamento, de sondagem e de ensaio de avaliação de impactes), satisfazem os requisitos metodológicos da Arqueologia da Arquitectura, proporcionando resultados interessantes para a discussão da evolução do sistema defensivo medieval e da morfologia urbana moderna.

\section{CASOS DE ESTUDO}

\subsection{Metodologias}

A Arqueologia da Arquitectura incorporou, nos últimos anos, significativos desenvolvimentos teóricos e técnicos, que se traduzem, actualmente, numa reconhecida potencialidade de renovação dos estudos de história da arquitectura e numa capacidade de actuação qualificada na área da conservação e valorização do património edificado (Caballero Zoreda 2006).

O aparato metodológico da Arqueologia da Arquitectura tem vindo a aperfeiçoar-se, comportando já um conjunto de procedimentos bem estabelecidos, que incluem: Pesquisa documental; Prospecção; Levantamento gráfico e fotográfico rigoroso; Descrição (constituição de base de dados, com registo das diferentes categorias de dados); Análise das relações estratigráficas e definição das actividades construtivas; Determinação genérica das fases construtivas; Cruzamento dos dados das estratigrafias de alçados, dos registos de escavações e da documentação escrita, para elaboração da interpretação da evolução arquitectónica do edificado (fases da história do edifício ou de conjuntos de edifícios); Síntese histórica contextualizada.

Sobre esta matéria vejam-se os inúmeros contributos veiculados na revista Arqueologia de la Arquitectura, editada pelo CSIC/UPV, onde se recolhe abundante bibliografia, designadamente no n. ${ }^{\circ} 6$ (VV.AA. 2009b),

Nos três casos aqui apresentados, importa referir, do ponto de vista instrumental, que as leituras estratigráficas dos alçados se fizeram por observação directa, registandose no edifício 2.2.1 sobre fotografia ortorectificada simples e no edifício 2.2.2 sobre levantamento obtido por restituição fotogramétrica - para as técnicas e sistemas de levantamento ver Groetelaars e Amorim (2004) e Mateus et alii (2008).

Procedeu-se à identificação e caracterização das unidades estratigráficas construtivas e sedimentares, registandose toda a informação recolhida na base de dados do Sistema de Informação desenvolvido pela Unidade de Arqueologia no âmbito do Projecto de Salvamento de Bracara Augusta, que comporta módulos específicos para caracterização de edificado. A estratigrafia identificada foi sequenciada em diagrama, de acordo com metodologia 'Harris' e com base na aplicação informática ArchEd (https://www.ads.tuwien.ac.at/ArchEd/).

Relativamente à utilização das fontes documentais, deve assinalar-se que Braga possui um conjunto significativo de documentação e cartografia históricas, cujo conhecimento é imprescindível para a compreensão da evolução 


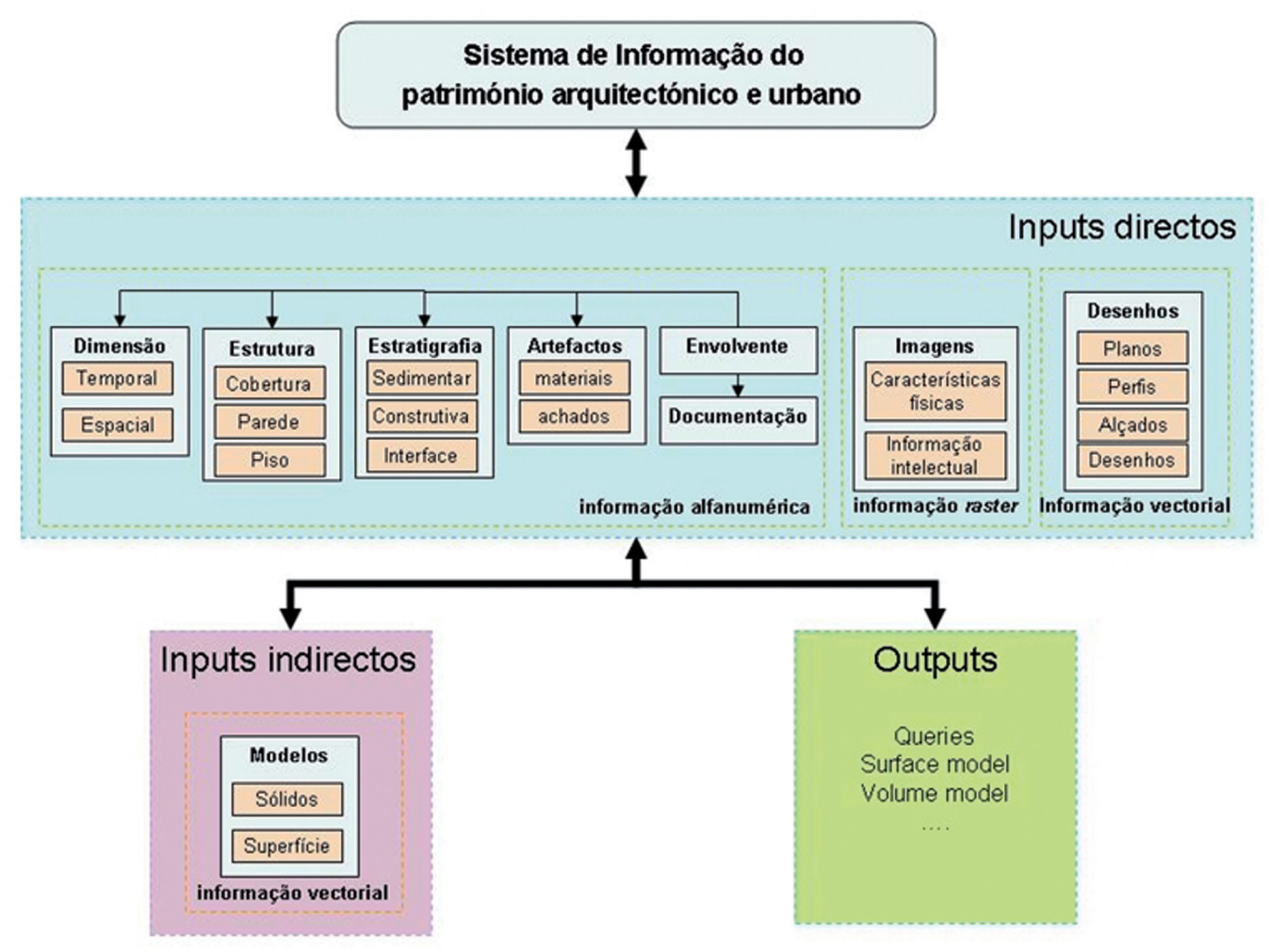

Fig. 2. Esquema simplificado da estrutura da base de dados arqueológicos

urbanística da cidade, em especial a partir do século XVI (Ribeiro 2008:190 e sgs.).

De facto, para além das actas de vereações da Câmara, de contratos de emprazamento, de alguns manuscritos privados, dos registos da Mitra e do Cabido, em que se destaca o Índice dos Prazos do Cabido, conservam-se diversas representações iconográficas e cartografias antigas da cidade.
Neste nosso estudo, consideraram-se como instrumentos fundamentais de análise regressiva o célebre $M A$ PPA DAS RUAS DE BRAGA DE 1750, da autoria de Ricardo da Rocha (MRB 1989/91) e o MAPA DA CIDA$D E D E B R A G A$ de 1883-1884, à escala 1:500, executado por Francisco Goullard, conservado no Arquivo das Obras da Câmara Municipal de Braga.

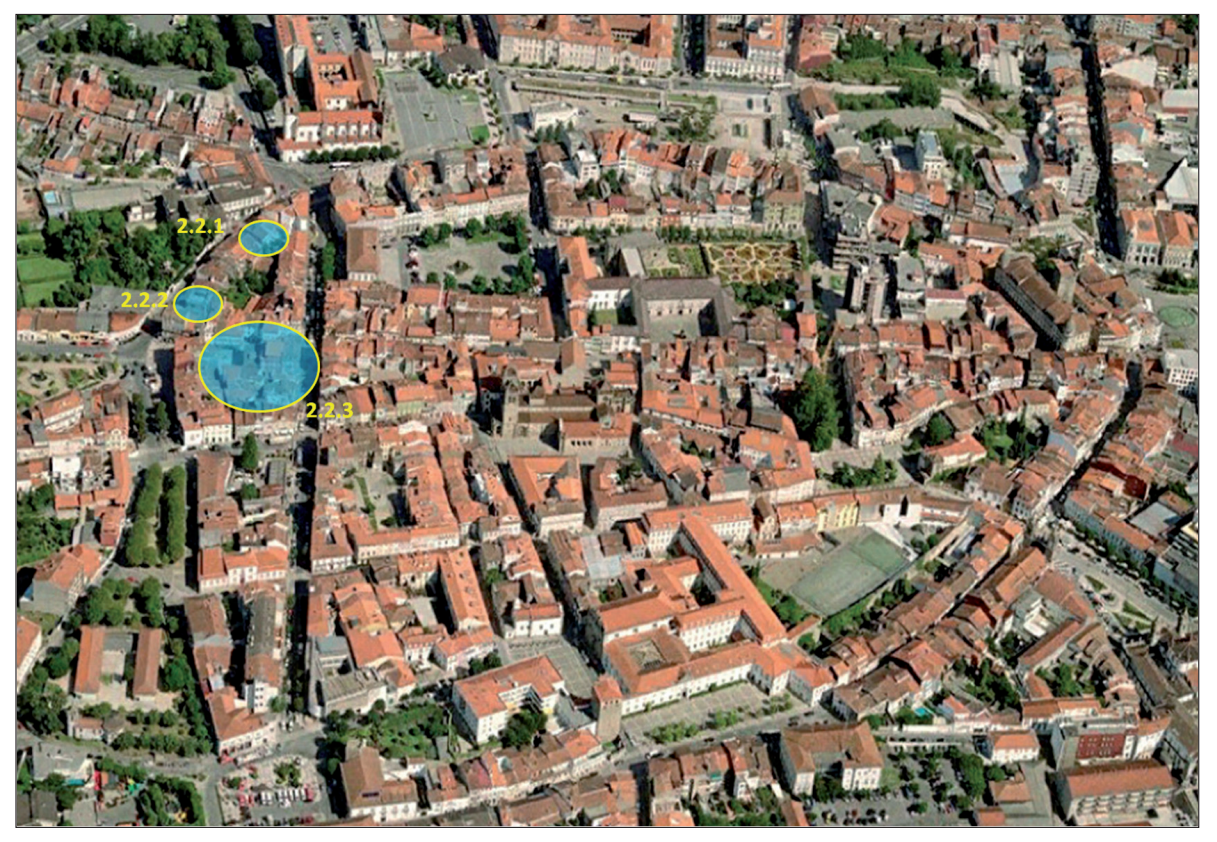

Fig. 3. Localização das intervenções arqueológicas referidas no estudo 
No caso de estudo da Praça Velha, a análise do módulo dos loteamentos e da expressão arquitectónica das fachadas fez-se partindo da confrontação entre o existente e o historicamente documentado, procurando identificar padrōes e simultaneamente evidenciar as alterações mais significativas da sua matriz urbana. Procedeu-se à caracterização das fachadas em fichas desenhadas para o efeito e manipularam-se as fotografias com AdobePhotoshop. Os modelos volumétricos foram projectados sobre cartografia histórica através do programa Google SketchUp.

\subsection{Resultados}

\subsubsection{Edifício n. ${ }^{\circ} 43-49$ da Rua dos Biscainhos}

O edifício com os n. ${ }^{\circ} 43-49$ da Rua dos Biscaínhos (2.2.1 da Fig. 2), para o qual se viabilizou um projecto de intervenção arquitectónica, integra parte da muralha medieval, localizando-se, portanto, em zona de condicionamento arqueológico e arquitectónico, pelo que foi objecto de acompanhamento arqueológico para registo de possíveis vestígios arqueológicos.

Trata-se de um edifico reconstruído em meados do século XX, com reaproveitamento parcial de paredes de alvenaria granítica irregular pré-existentes e sem especial qualidade arquitectónica, utilizado como estabelecimento comercial no piso inferior e habitação nos pisos superiores. A intervenção, que revestiu o carácter de acompanhamento, pois o projecto arquitectónico já estava aprovado, teve como principais objectivos: a) registar a estratigrafia do alçado poente da muralha; b) acompanhar o desaterro do solo até à profundidade de $0,50 \mathrm{~m}$ e verificar a eventual existência de vestígios arqueológicos no subsolo.

Os trabalhos arqueológicos de registo foram executados em momentos distintos, em fase de execução da obra,

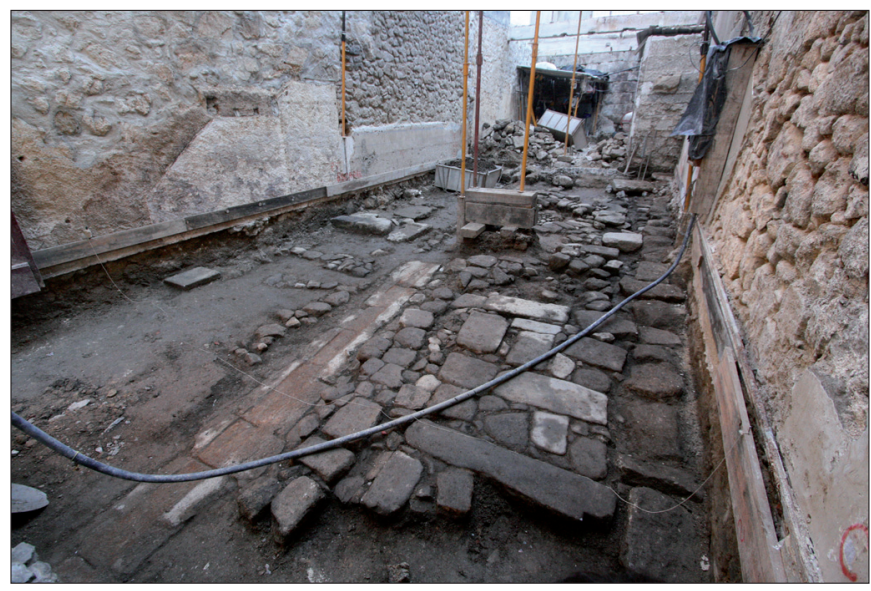

Fig. 4. Perspectivas do interior do edifício após demolição optando-se por registar em separado as sequências estratigráficas do solo e do alçado.

\section{Acompanhamento da remoção do pavimento do piso 0 (r/c)}

Ao nível do piso 0 , após a remoção do pavimento cerâmico, identificaram-se no compartimento da cozinha duas canalizações (UEs.0011/0010, 0094) com orientação Sul/ Norte, em granito. A primeira (UE.0011/0010), localizada a Oeste, desembocava noutra conduta de características construtivas semelhante e com orientação Este/Oeste. A segunda (UE.0094), situada a Este, encontra-se associada a um tanque rectangular (UE.0095). Decorrendo da mesma acção foi posto a descoberto o alicerce da muralha medieval (UE.0054/0061).

Para além destas estruturas, detectaram-se sob os degraus da escada que divide estes compartimentos, a presença de uma soleira e de uma ombreira (UE.0008).

No compartimento setentrional, identificaram-se três canalizações (UEs.001/003, 0005/0006 e 0025), bem como a conduta referida anteriormente (UE.0011/0010), que se prolongava para Norte. Observou-se, dada a inexistência de cobertura pétrea, que os blocos afeiçoados e tendencialmente rectangulares que compõem o seu leito, apresentavam as mesma características construtivas que os pavimentos contíguos (UEs.0030, 0031 e 0029), parcialmente destruídos, indicando assim um reaproveitamento de materiais para sua construção.

Associados a estas estruturas, registaram-se diversos vestígios de pavimentos pétreos (UEs.0002, 0014, 0016, 0017, 0018, 0020, 0021, 0022, 0023, 0027, 0029, 0030, $0031=0032$ e $0040=0042$ ), vários interfaces de ruptura associados à destruição (UEs.0041, 0044, 0045, 0046 e 0053) e/ou reestruturação destes mesmos pisos (UEs.0049=0050 e 0052) e as respectivas camadas de

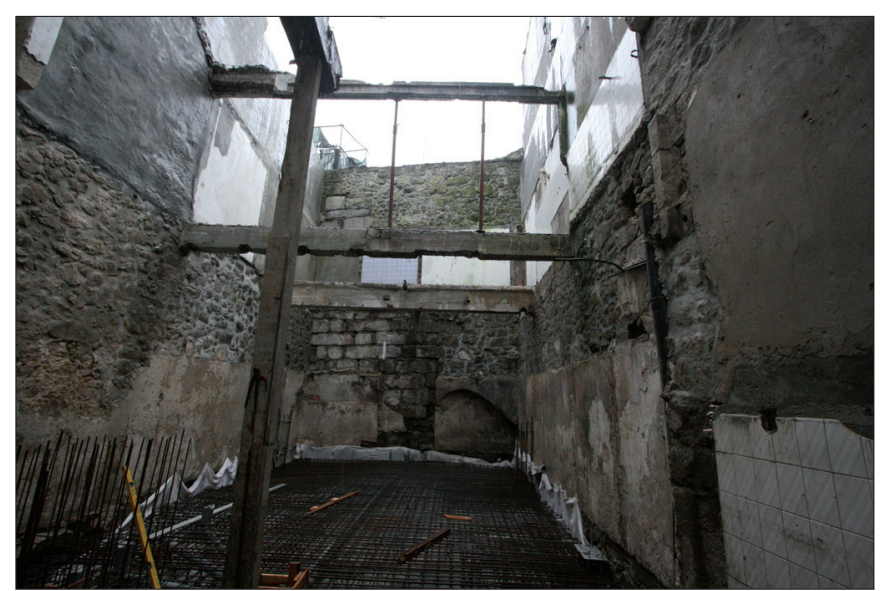




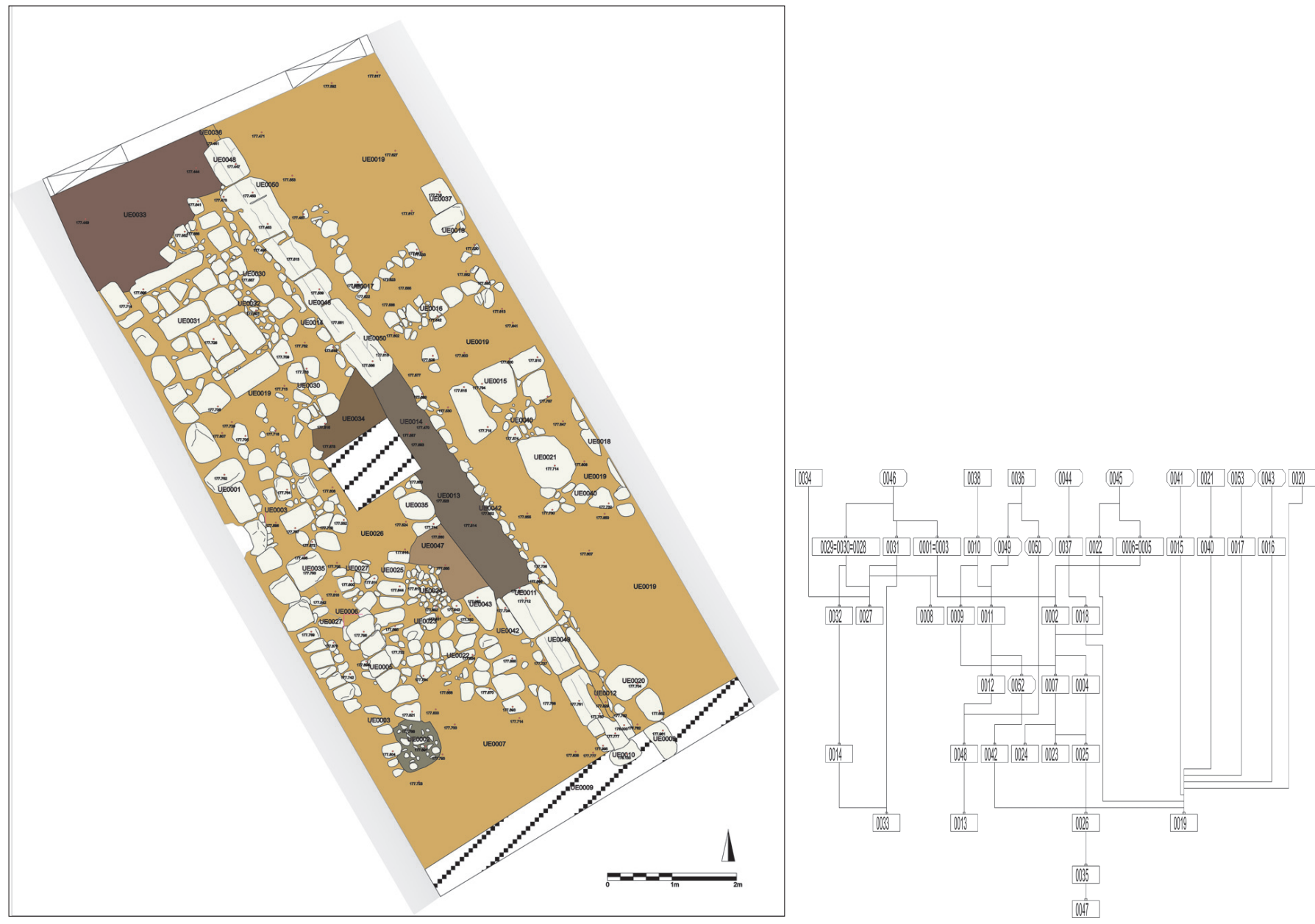

Fig. 5. Levantamento dos vestígios de época contemporânea no compartimento Norte e respectivo diagrama da sequência estratigráfica

assentamento (UEs.0013, 0019, 0026, 0033, 0034 e 0047). Estes pavimentos apresentam uma grande diversidade no afeiçoamento e tratamento do granito utilizado.

Foi possível ainda registar algumas sobreposiçōes, o que permitiu individualizar três fases de ocupação: A primeira relacionada com a construção do tanque (UE.0095) e da conduta (UE.0094). Estas estruturas são semelhantes às encontradas no prédio 89-96, localizado na mesma rua (ver mais abaixo, subcapítulo 2.2). O tanque evidencia uma técnica construtiva diferente, mas a sua presença sugere uma organização espacial idêntica. Os restos de pavimentos em calçada poderiam correlacionarse com esta ocupação; A segunda fase corresponde à construção da canalização (UE.0011/0010) que está directamente associada à construção dos degraus e alicerce do arco da parede divisória, que desactivou a conduta e tanque a Sul e as duas canalizações a Norte (UEs.0025 e 0001/0003); A terceira fase estará ligada à reestruturação da conduta (UE.0010/0011) materializada pelo rasgo (UE.0049) feito para a colocação do cano de grés
(UE.0036) e construção de um murete de alvenaria de tijolo e cimento para a sua protecção lateral (UE.0012), com destruição de pisos contíguos e reaproveitamento de blocos no seu leito (UEs.0002, 0014, 0016, 0017, 0018, 0020, 0021, 0022, 0023, 0027, 0029, 0030, 0031=0032 e $0040=0042)$.

De acordo com a posição estratigráfica relativa e considerando a cronologia de reconstrução do edifício, de meados do século XX, propõe-se para a primeira fase uma datação situada no decurso do século XVIII, para a segunda fase os meados do século XX e para a terceira fase o terceiro quartel do século XX.

\section{Levantamento do alçado tardoz}

Após a conclusão do registo ao nível do piso 0 e libertação da zona Sul do prédio, efectuou-se o levantamento fotográfico e topográfico do alçado da muralha medieval, correspondente à parede da fachada tardoz do edifício. Com base na análise da informação recolhida, sequenciaram-se as seguintes fases construtivas: 


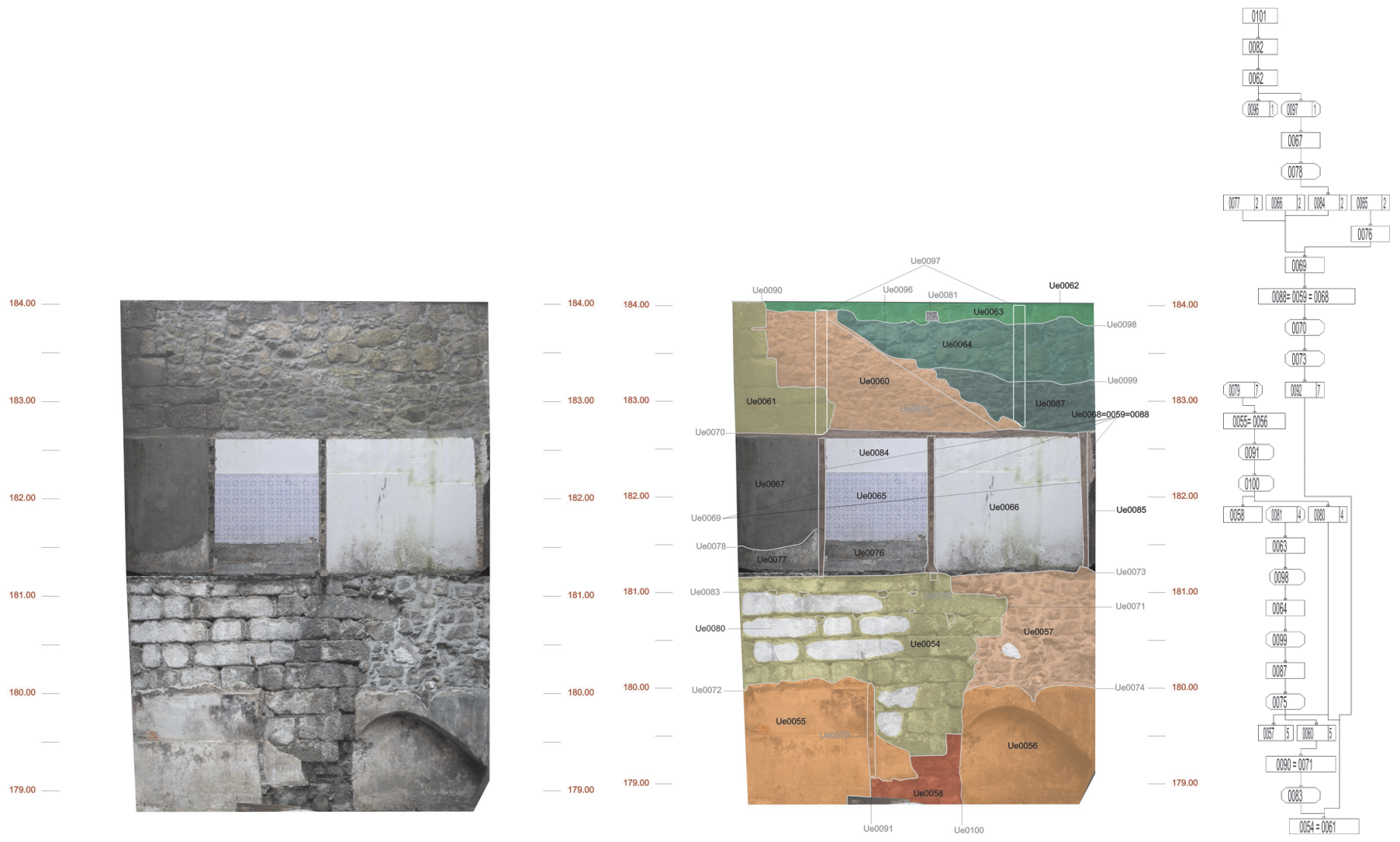

Fig. 6. Leitura estratigráfica do alçado tardoz do edifício, com identificação do paramento da muralha medieval (UE. 0061=0054) e diagrama da sequência estratigráfica

Fase I - Corresponde à construção da muralha medieval (UE.0061=0054), documentalmente datada dos séculos XIII-XIV (Marques 1986).

Fase II - Incluíram-se nesta fase os mais antigos vestígios de um edifício que adossou exteriormente à muralha. Materializa-se por um tramo de parede em alvenaria de pedra miúda (UE.0057=0057), sobre o qual se aplicou o primeiro tipo de revestimento, uma camada de caiação (UE.0080). O negativo de empena (UE.0075) sugere a existência de um telhado, o que implica, relativamente à cota actual, um rebaixamento dos diferentes níveis de circulação. Associamos a esta ocupação, a construção do poço/tanque e canalização.

De acordo com a posição estratigráfica relativa e com o contexto de evolução arquitectónica do quarteirão dos Biscainhos, estes vestígios corresponderão a uma edificação setecentista.

Fase III - Caracteriza-se pelo aumento de mais um piso (UEs.0087, 0064, 0063, 0098 e 0099), incorporando na fiada superior um bloco com entalhe rectangular, que funcionaria como remate da parede e apoio para viga ou barrote (UE.0081). As diferenças evidenciadas entre estes aparelhos poderão constituir etapas de obras.
No piso 0, esta fase corresponde à parede divisória em arco, à colocação de escadas (UE.0091) e revestimentos (UEs.0055 e 0056), indiciando uma subida de cota do piso 0 , no compartimento a sul, que deste modo inutilizou o tanque/poço e motivou a construção das diversas condutas exumadas. $\mathrm{O}$ achado da soleira e ombreira junto à parede oeste, corrobora esta interpretação.

Propõe-se para esta etapa construtiva uma cronologia correspondente à reconstrução do edifício em meados do século $\mathrm{XX}$.

Fase IV - Estará associada à configuração do prédio antes da intervenção actual, com somente 1 piso, desaparecendo o segundo para dar lugar a um anexo traseiro (UEs.0097 e 0096), com acesso ao exterior sobre a muralha. O paramento ainda conservava os diferentes revestimentos (UEs.0067, 0076, 0077, 0078, 0065, 0084, 0085, 0068, 0059 e 0088) e negativos (UE.0069) de paredes divisórias, que organizavam o espaço neste andar.

No piso 0, associam-se a esta fase a parede «caixa-dear» em alvenaria de tijolo e revestimentos de azulejo e de argamassa pintada. Estes vestígios articulam-se com a elevação de cota do piso no compartimento Sul, com construção de degrau e reconstrução da canalização com 
colocação de tubagem de grés (UEs.0010, 0011 e 0036), desactivando-se as canalizações anteriores.

Esta fase corresponderá a uma remodelação interior do prédio no terceiro quartel do século XX, com adaptação do piso térreo a estabelecimento comercial.

Constatou-se que a fachada tardoz do edifício ainda conservava vestígios da muralha medieval, tendo o seu registo permitido compreender a evolução construtiva das edificações que se lhe sobrepuseram.

Recomendou-se a conservação do tramo de muralha medieval e sua integração arquitectónica na nova obra.

Ao nível do subsolo, verificou-se que o desaterro efectuado para execução da obra nova não ultrapassou a profundidade projectada, o que permitiu conservar in situ os vestígios das pavimentaçôes anteriores, que foram protegidos com tela geotêxtil e selados por um ensoleiramento de betão.

\subsubsection{Edifício n. ${ }^{\circ} 89-97$ da Rua dos Biscainhos}

O edifício com os n. ${ }^{\circ} 89$ a 97 da Rua dos Biscaínhos (2.2.2 da Fig.2), situa-se junto à torre medieval dita da Porta Nova, encostando à sua face poente. Trata-se de um edifico que foi consumido por um incêndio no ano de 2006, que destruiu praticamente todo o seu interior, cujos restos foram demolidos, por razões de segurança, em 2007. Conservou-se apenas a fachada, datável do século XVII, em alvenaria irregular de granito, com vãos de portas e janelas compostos por guarniçōes de cantaria granítica afeiçoada.

Por se localizar em zona de condicionamento arqueológico e arquitectónico, foi objecto de trabalhos arqueoló- gicos preliminares, devendo assinalar-se que, ao contrário do exemplo anterior, a intervenção arqueológica teve lugar antes da execução da obra, destinando-se, assim, a avaliar os eventuais impactes sobre possíveis vestígios arqueológicos e a informar a elaboração do novo projecto de arquitectura.

Esta intervenção teve como principais objectivos: a) registar e interpretar a estratigrafia do alçado poente da torre medieval; b) verificar a existência de vestígios arqueológicos no subsolo; c) avaliar as condicionantes do projecto de arquitectura previsto para o local. Os trabalhos de escavação e de levantamento do alçado executaram-se em simultâneo, optando-se aqui por efectuar a leitura integrada da sequência estratigráfica.

\section{Sondagem 1}

Deu-se início aos trabalhos fotografando a área de intervenção tal como se encontrava. Procedeu-se a uma limpeza inicial e posteriormente implantou-se a quadrícula correspondente à sondagem 1 (S1). Elaborou-se o Plano 1, no qual se identificaram as UEs.001 a 027, 029, 030, 031, $037,180,181$ e 184 , correspondentes às pavimentaçōes, às paredes e demoliç̧óes do edifício preexistente.

A escavação permitiu identificar estruturas e aterros correlacionados com as diversas edificações que ocuparam o local, destacando-se uma bica e tanque de recepção de água com caleira de elementos monolíticos de vazamento, que se atribui ao século XVII e uma levada de água anterior, quinhentista, que deveria drenar a linha de água que corria no talvegue, correspondente à actual rua $\mathrm{D}$. Diogo de

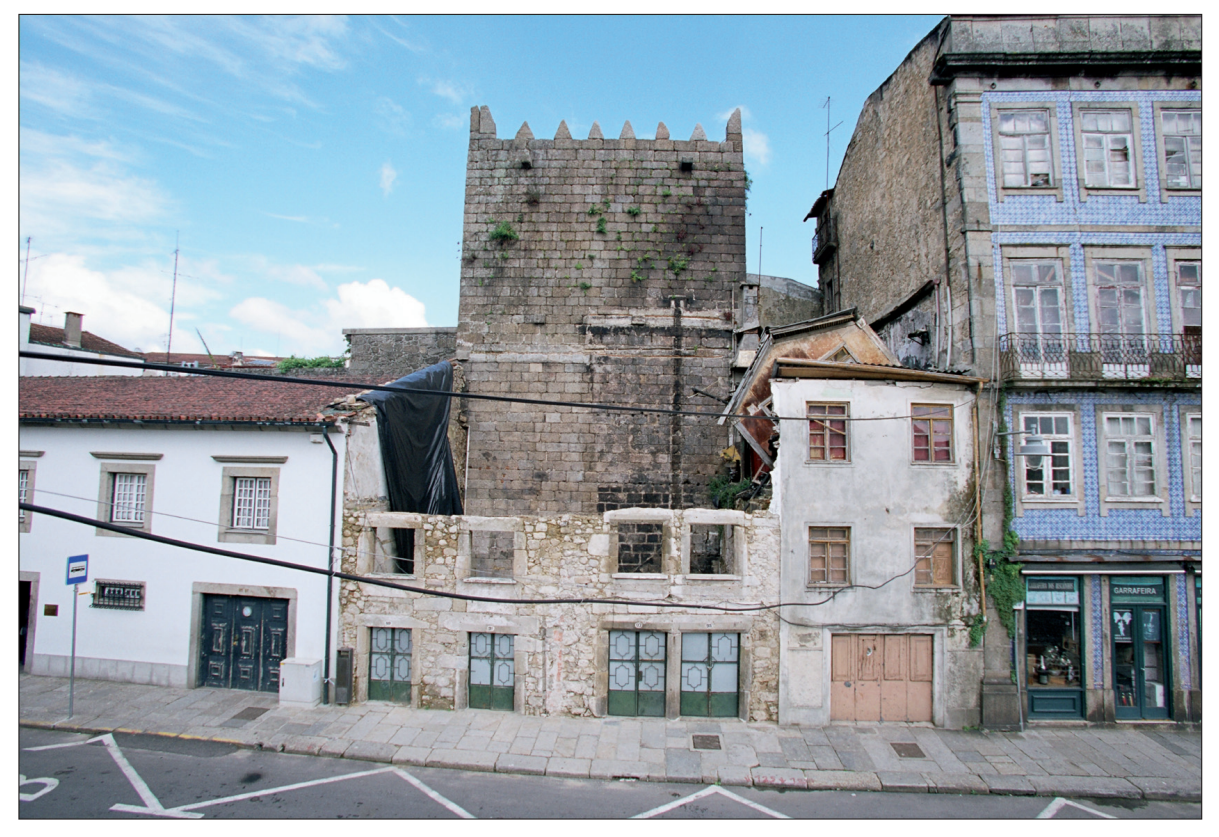



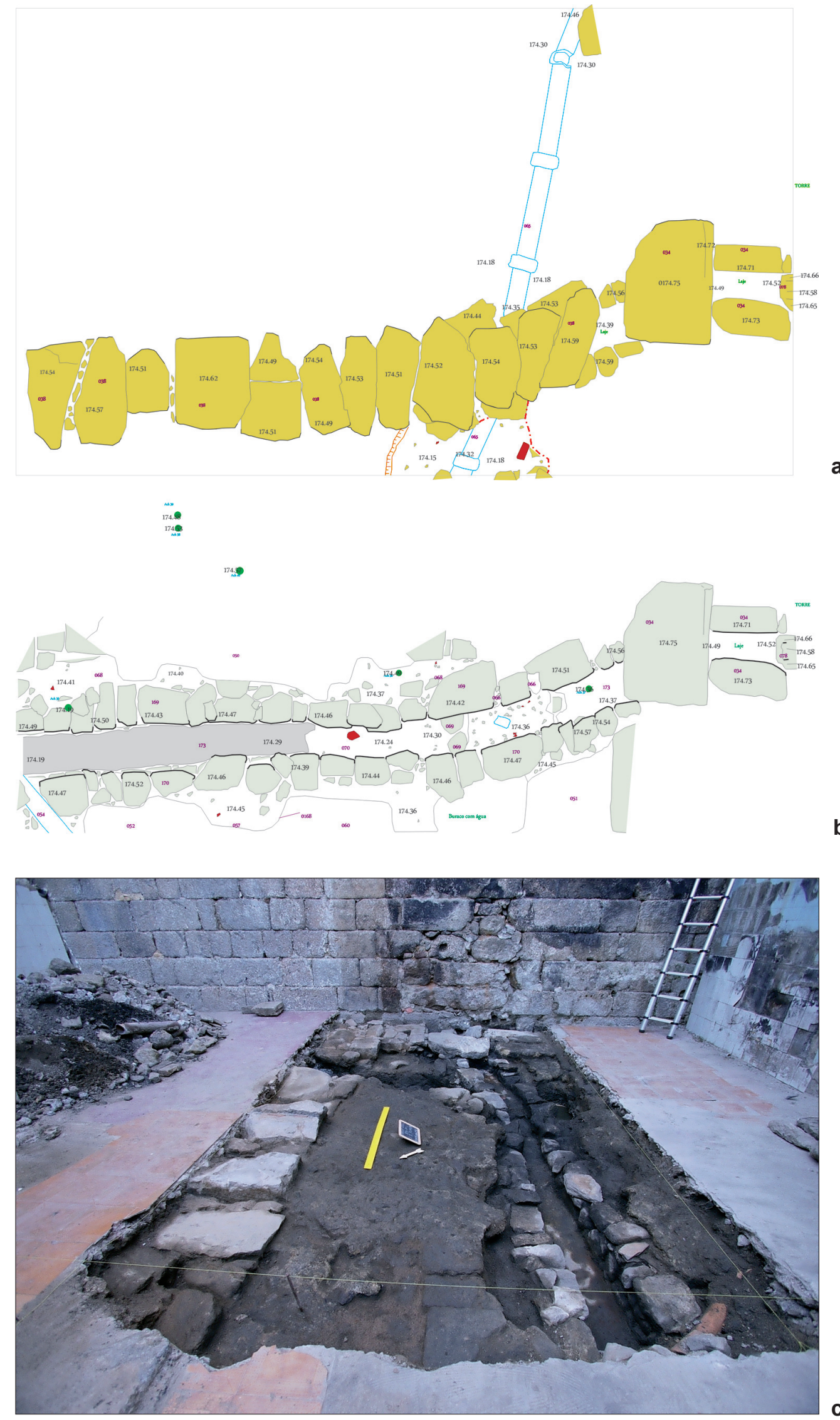

Fig. 8 a, b, c. Registos das diversas canalizações identificadas na Sondagem 1 e diagrama da sequência estratigráfica 

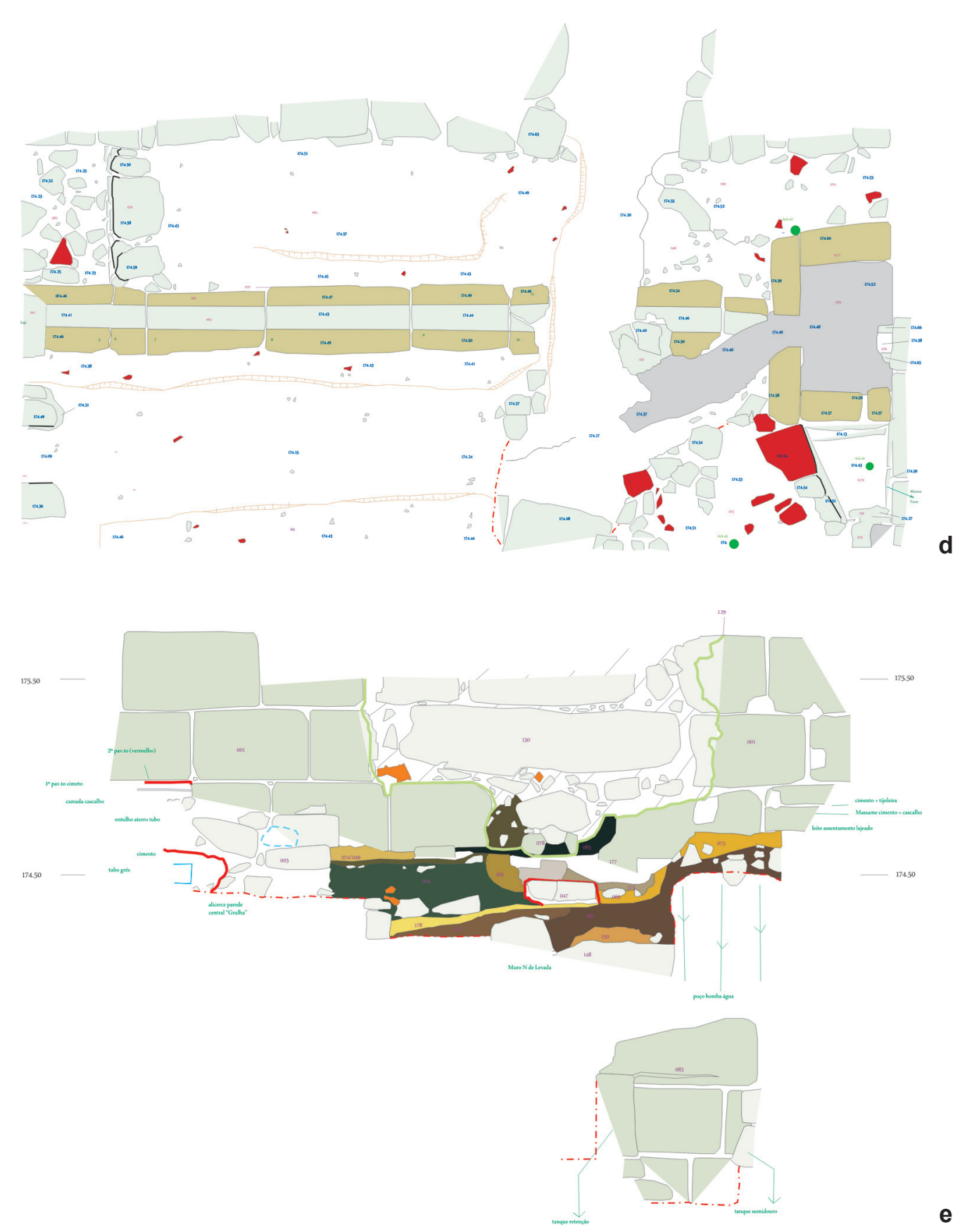

Fig. 8 d, e. Registos das diversas canalizações identificadas na Sondagem 1 e diagrama da sequência estratigráfica

Sousa e que terá sido aterrada com a ampliação da cerca medieval para Norte.

Sob estas estruturas identificou-se uma potente camada de aterro com elementos construtivos de tipologia romana e/ou medieval, que corresponderá à demolição de estruturas de épocas anteriores, medievais e romanas. A escavação arqueológica foi suspensa à superfície desta camada.

Recolheram-se 1315 elementos de espólio, sendo que $77,92 \%$ são fragmentos de cerâmica, $14,8 \%$ vidros, $3,65 \%$ metais diversos, $3,26 \%$ moedas e uma percentagem residual de líticos e outros, com $0,15 \%$ cada. Individualizaram-se em registo próprio 44 Achados, 43 dos quais moedas e 1 adorno.

A cerâmica apresenta-se muito fragmentada, identificando-se apenas 6 perfis completos. Os fragmentos apresentam-se generalizadamente com os bordos/arestas boleados, denunciando a sua mobilização em contextos de abandono e de aterro. Dominam as produções modernas e contemporâneas (séculos XVI-XX), predominantemente de- 


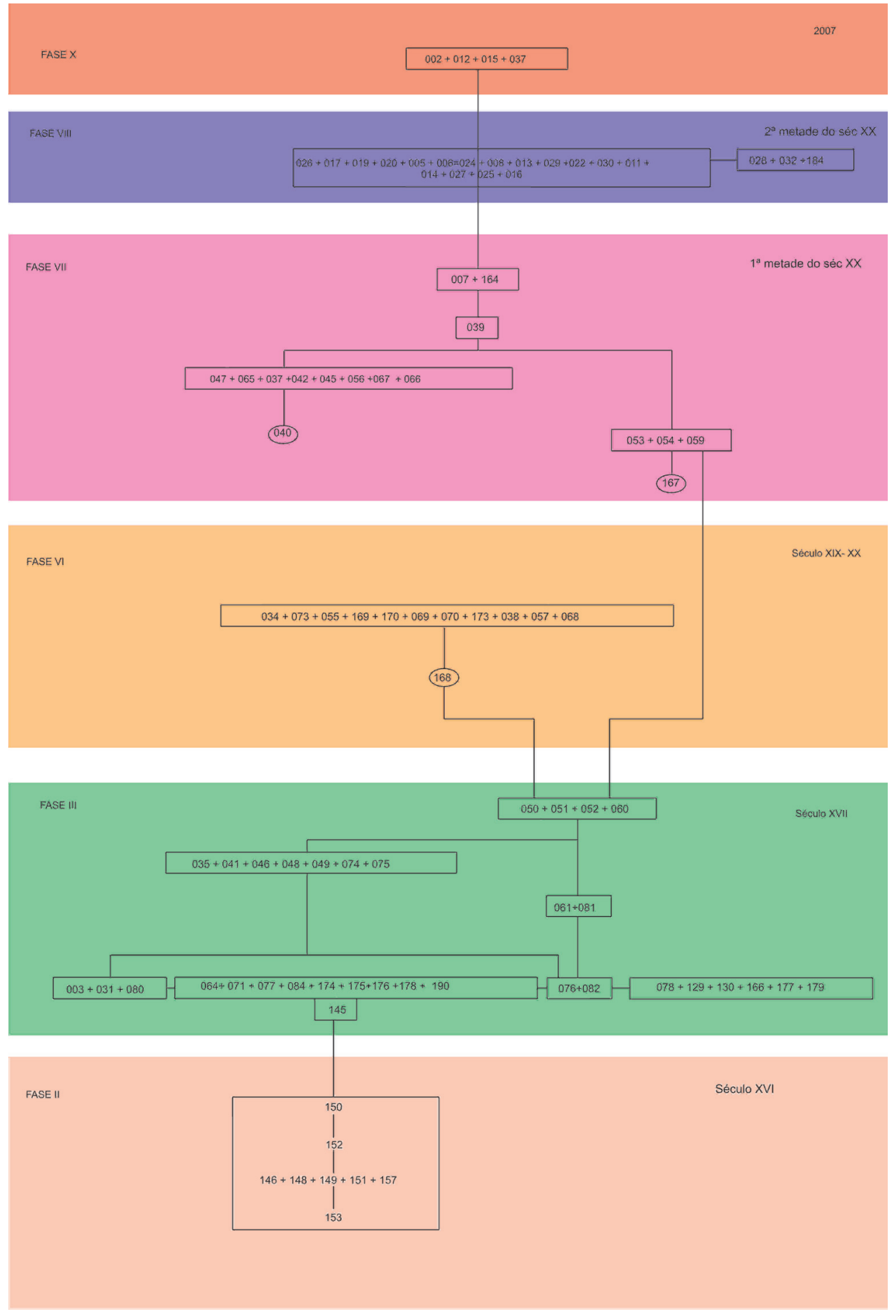

Fig. 8 f. Registos das diversas canalizações identificadas na Sondagem 1 e diagrama da sequência estratigráfica

fabricos locais (tipo Braga e Barcelos), sendo raros os fabricos regionais, que se evidenciam apenas nas faianças (Coimbra e Gaia/Porto).

Nos contextos anteriores à levada do século XVI, apenas se recolheram produçốes romanas e medievais, destacando-se um fragmento de tigela de fabrico bracaren- se e alguns fragmentos de fabricos locais redutores, característicos do período suevo-visigótico.

Os vidros são, quase na sua totalidade, fragmentos de vidraças modernas e contemporâneas, identificando-se raros fragmentos de peças de época romana, de forma indeterminada. Os metais diversos são predominantemen- 


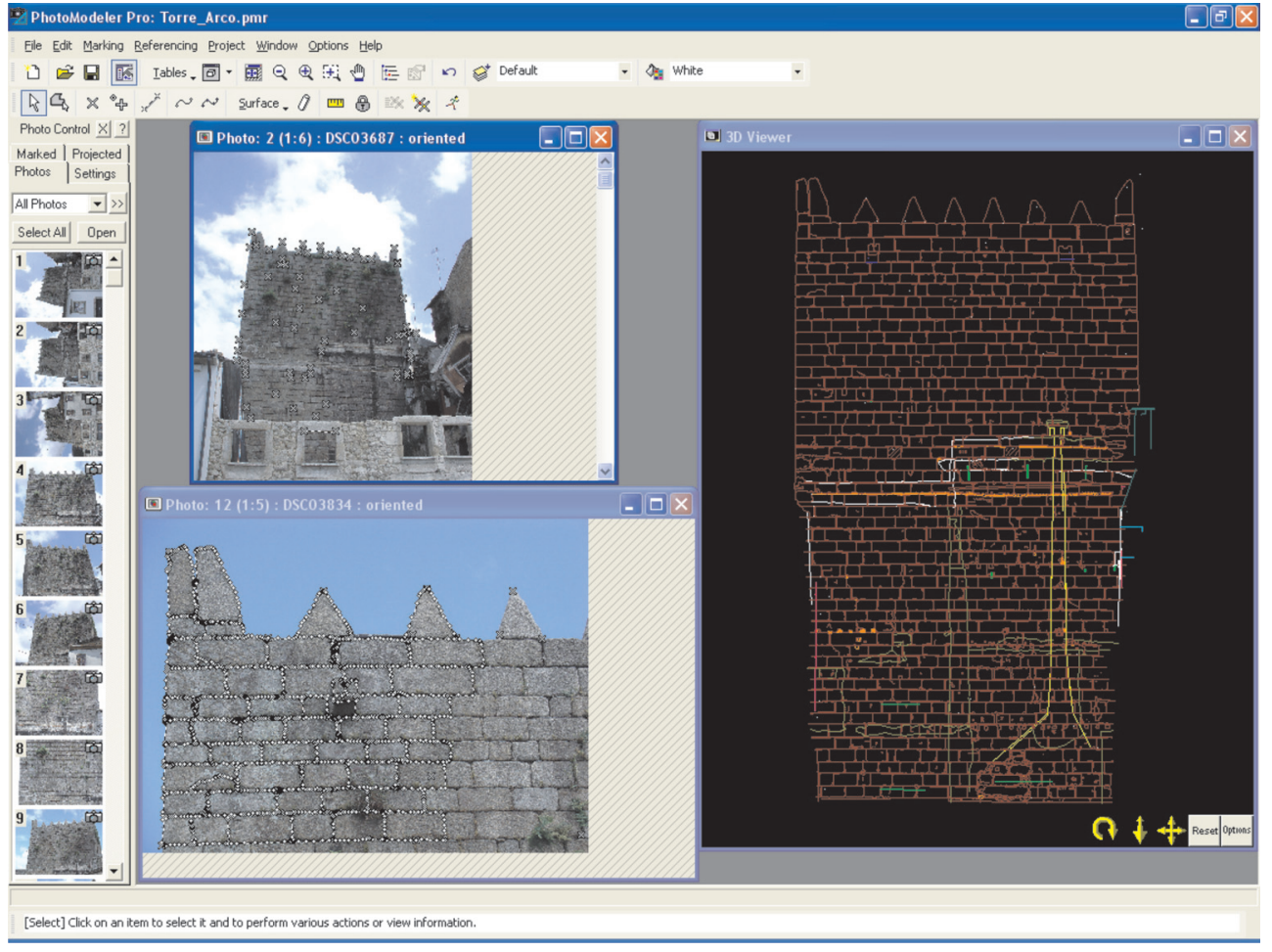

Fig. 9. Processamento da restituição fotogramétrica do alçado te pregos de ferro, de época moderna e contemporânea. As moedas encontram-se em muito mau estado de conservação, podendo apenas adiantar-se que, pelo contexto de proveniência e pelos módulos dominantes, se trata de moedas já da República Portuguesa.

\section{Leitura do alçado da torre}

Os trabalhos arqueológicos iniciaram-se com a remoção da vegetação da parte superior do alçado exterior da torre, com o objectivo de facilitar o registo fotográfico e melhor observar as suas características construtivas.

Procedeu-se então ao levantamento fotográfico digital, com máquina Nikon, calibrada para a restituição por fotogrametria de convergência, feita em PhotoModeler.5, a que se seguiu o processamento em AutoCad e posterior tratamento gráfico em CorelDraw (já com os dados da leitura estratigráfica interpretada).

Sobre um primeiro desenho do alçado procedeu-se à identificação dos diferentes contextos construtivos, sedimentares e interfaces e corrigiram-se e/ou acrescentaram-se pormenores do levantamento, elaborando-se posteriormente o desenho definitivo. Após uma primeira observação, através da qual se procurou apreender a evolução construtiva patenteada no alçado, associando conjuntos de vestígios, procedeu-se à numeração e descrição das unidades estratigráficas registadas nos levantamentos, carregando-se a informação na base de dados.
Entre as unidades estratigráficas construtivas foram identificados muros (UEs.001, 003, 018 e 029), canos (UEs.112 e 140), ferros de suporte (UEs.094, 095, 097, 123, 135 e 143), rebocos (UEs.004, 020, 085, 100, 101, 155, 156 e 158). Foram igualmente identificadas interfaces de ruptura representativas de acções de demolição (UEs.087, 092, 105, 113, 116, 118, 154 e 200), rasgos (UEs.111, 129 e 177) e furos para ferros de fixação (UEs.104, 108 e 120). Analogamente observou-se a presença de agulheiros alinhados para encaixe de vigas de madeira de pavimento sobradado (UEs.098, 126, 127, 128, 133 e 134), estabelecendo-se que o conjunto de agulheiros representado pela UE.126 terá tido, numa primeira fase, uma função de encaixe de vigas de madeira de cobertura de casa (telhada?). Estes alinhamentos permitem estabelecer as cotas dos pisos e coberturas e assim inferir a altura do pé-direito do edifício. As UEs.160, 162 e 163, representam agulheiros diversos. Distinguiram-se igualmente vestígios de rufos de telhado (UEs.090, 096, 125, 131 e 132), enchimentos de desactivação dos mesmos (UEs.121 e 122), enchimentos de agulheiros e rasgos (UE.124), designadamente do rasgo associado à colocação da bica de água (UE.130), bem como o enchimento das frestas (UE.142).

Distinguiram-se também elementos construtivos que integram a estrutura da própria torre, devido à sua funcionalidade específica: mísulas (UE.136), goteiras (UE.137); merlôes ou ameias (UE.138) e frestas (UE.141). 


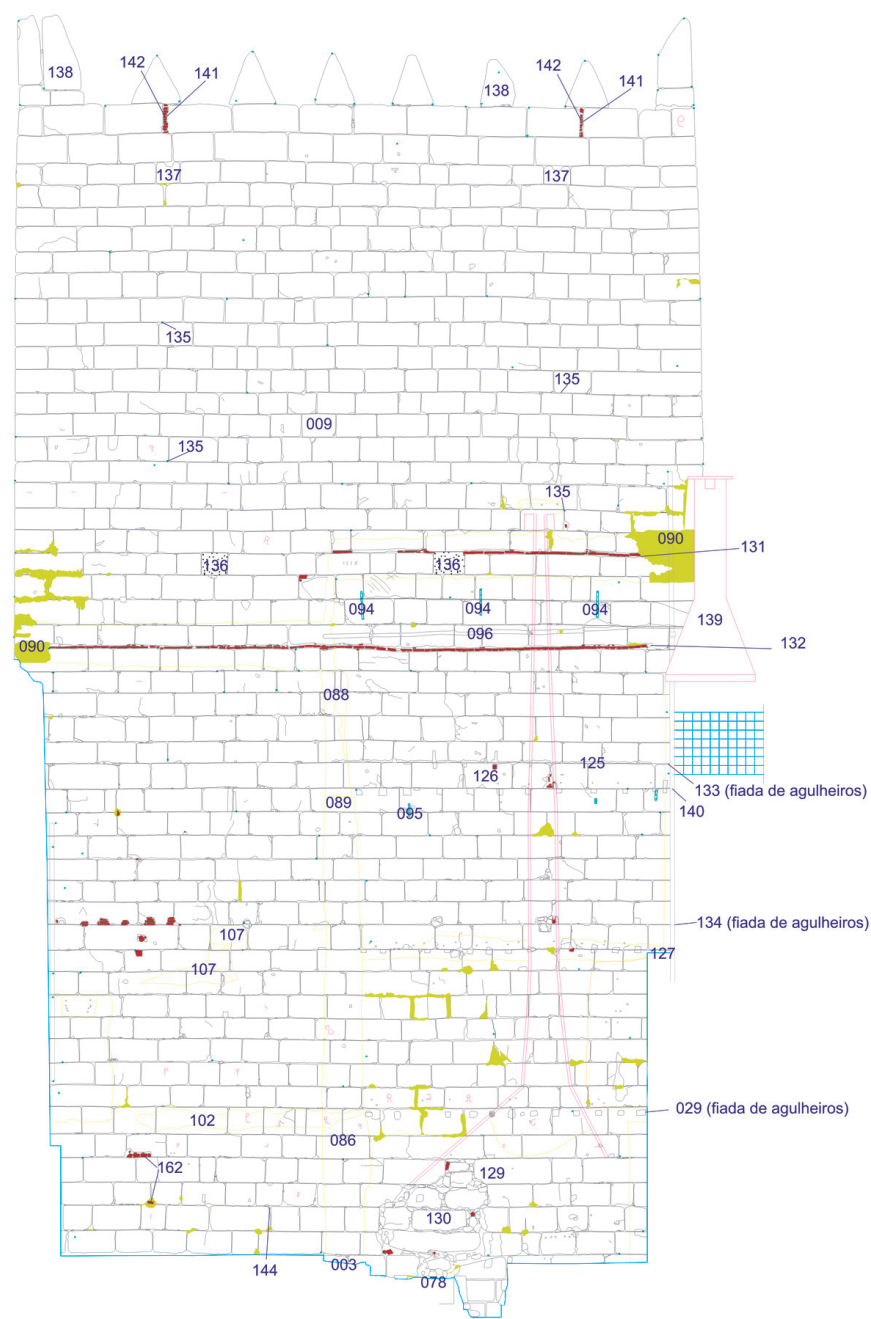

Fig. 10. Levantamento do alçado por restituição fotogramétrica

Foram identificadas diversas interfaces de ligação: manchas correspondentes ao encosto de paredes (UEs.086, 088, 089 e 155), de cobertura telhada (UE.091) e de calcinação de cor negra resultante do incêndio, a qual permite inferir os pisos (UEs.093, 102, 107, 109 e 161). Foram, do mesmo modo, registadas manchas correspondentes a negativos de compartimentos de casa de banho (UEs.103 e 104), de encosto da saia e canal de evacuação da chaminé (UE.115) e a mancha de fuligem correspondente à sua utilização (UE.119).

No edifício no 97 registou-se a existência de uma chaminé (UE.139), interfaces correspondentes a negativos de canalizações (UEs.099 e 117) e argamassas (UE.114) e (UE.144). Registou-se também a existência de uma variedade de revestimentos: em azulejo (UE.157) e caiação (UEs.106 e 159) e ainda uma bica de água em granito (UE.078), que corria para uma caixa de recepção de água (UE.177).

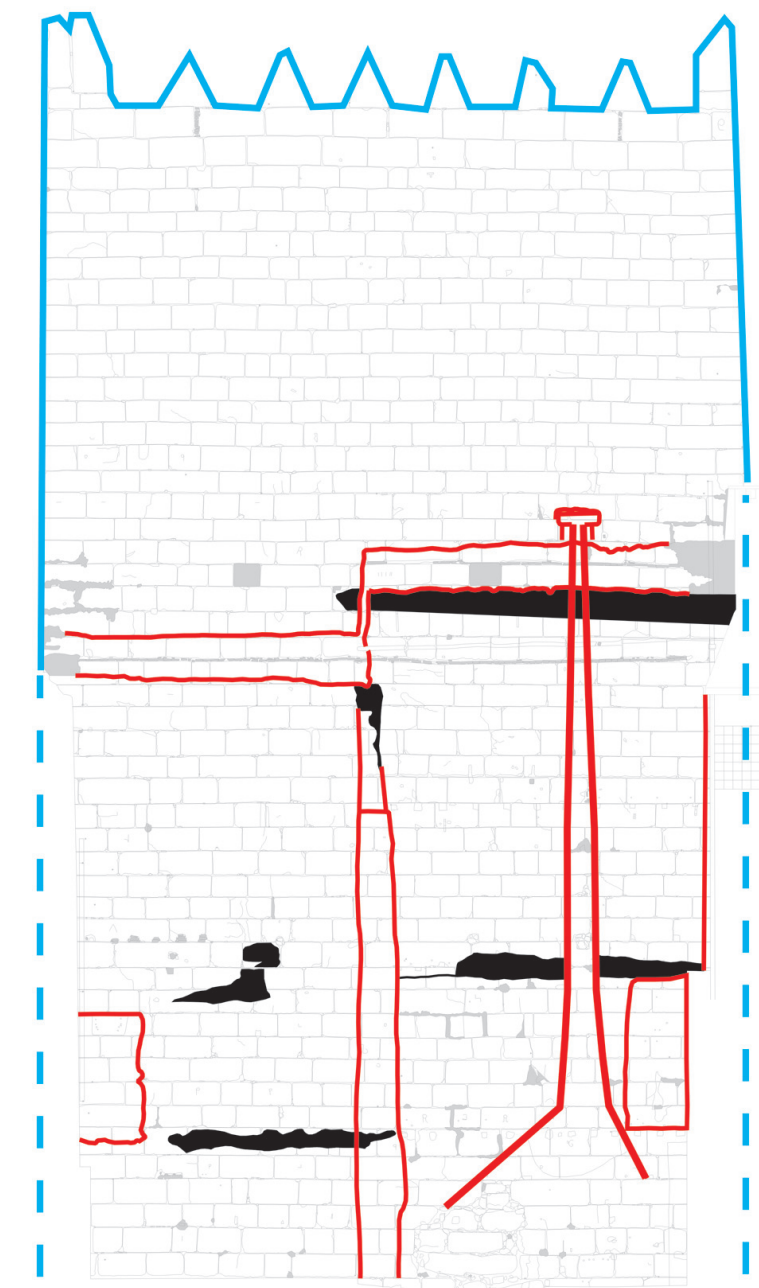

Fig. 11. Identificação dos interfaces de incêndio e demolição do edifício

Após a identificação das unidades estratigráficas, ensaiou-se a reconstituição da sequência construtiva das edificações que adossaram à torre, identificando-se 10 Fases (numeradas de I a X), as quais agrupam as UEs. anteriormente identificadas. Para o estabelecimento da sequência recorreu-se igualmente, porque a demolição do edifício foi um facto relativamente recente, às memórias orais existentes sobre o mesmo, nomeadamente sobre os compartimentos existentes e respectivas funcionalidades.

A fase construtiva mais antiga (Fase I), cronologicamente atribuível aos finais do século XIV e inícios do século $\mathrm{XV}$, corresponde à edificação da torre tardomedieval, que tinha como função defender o postigo próximo. As unidades estratigráficas associadas a esta Fase são (UEs.001, 136, 137, 138, 141 e 144).

A Fase II foi interpretada como correspondente à implantação de uma levada, a que se atribuiu uma cronologia genérica do século XVI, associando-a à drenagem do 


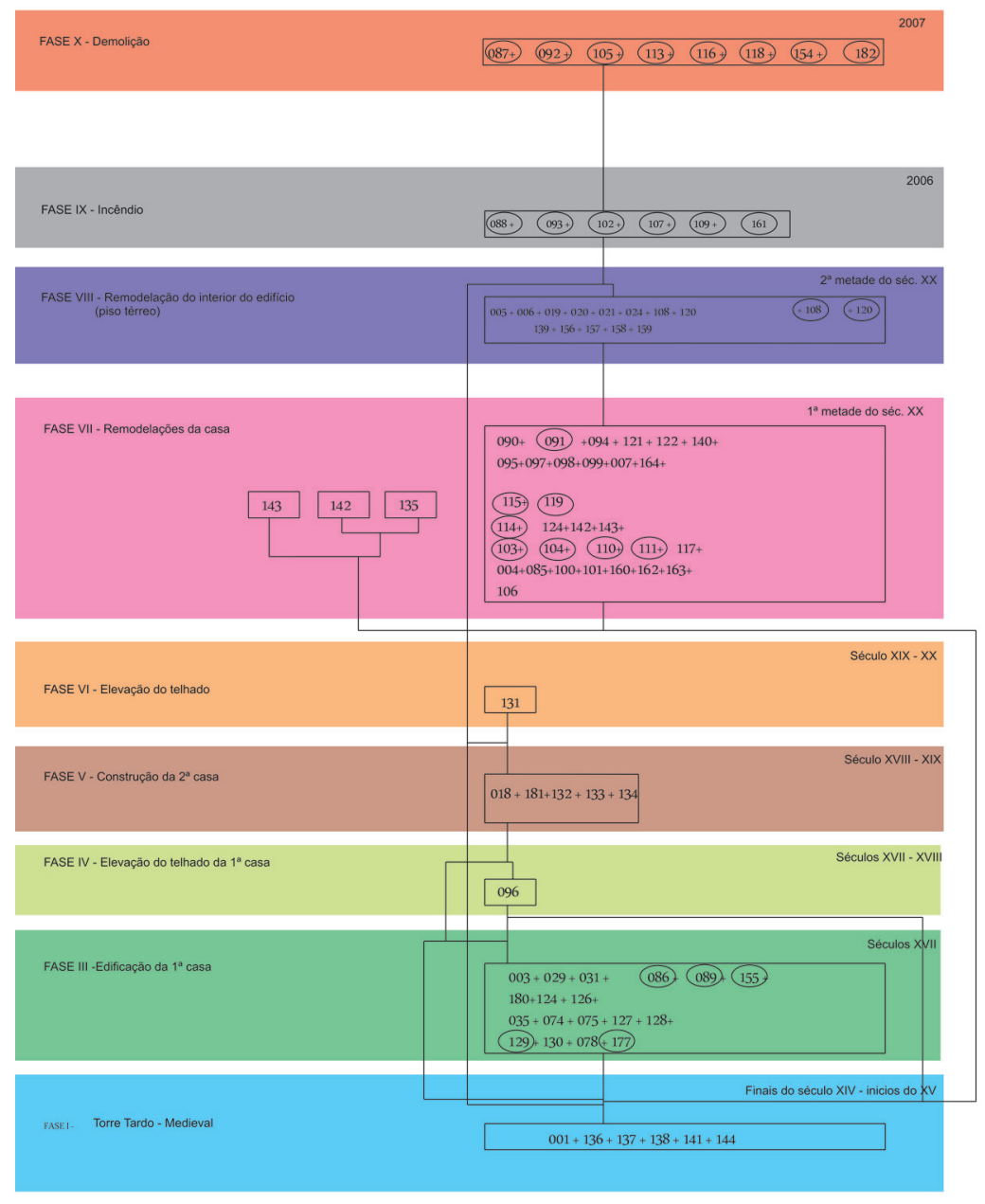

Fig. 12. Diagrama da sequência estratigráfica

talvegue correspondente ao traçado da Rua de D. Diogo de Sousa, espaço que conheceu profundas alteraçóes no decurso dos séculos XV e XVI. Esta Fase foi identificada apenas na Sondagem 1, não se registando vestígios directamente relacionados com a torre.

A Fase III corresponde à edificação da primeira casa contra o alçado da torre, propondo-se uma cronologia em torno do século XVII. Desta possuímos vestígios que nos indicam a existência de paredes (UEs.003, 031, 086, 089, 155 e 180), cobertura de telhados (UEs.125 e 126), pisos (UEs.035, 074, 075, 127 e 128) e tanque de água (UEs.078, 129, 130 e 177) A distância entre os alinhamentos de agulheiros e entre estes e o rufo do telhado evidenciam a regularidade da altura dos pés-direitos da habitação, com cerca de $2,5 \mathrm{~m}$.

A Fase IV, datável entre os séculos XVII e XVIII, foi interpretada como correspondente à elevação do telhado da primeira casa, representada por um rufo (UE.096), obtendo-se um terceiro piso, com reaproveitamento dos agulheiros do anterior telhado (UE.126) para apoio do sobrado.
$\mathrm{Na}$ Fase V, cronologicamente balizada entre os séculos XVIII-XIX, ocorre a construção da segunda casa, que amplia a primeira para Norte e se materializa em paredes (UE. 018), novo telhado (UE.132) e pisos (UEs.133 e 134).

Seguidamente (Fase VI), procedeu-se a uma nova elevação do telhado, representada pelo rufo de telhado correspondente ao rasgo horizontal (UE.131), aberto provavelmente no século XIX.

$\mathrm{Na}$ primeira metade do século $\mathrm{XX}$, ocorreu uma fase de remodelaçôes da casa (Fase VII), expressa por rufo de telhado (UE.090), mancha de encosto de cobertura telhada (UE.091) e ferros de suporte de viga (UEs.094 e 095), preenchimentos de rufos, agulheiros, juntas e diversos rasgos (UEs.114, 121, 122, 124, 160, 161, 162 e 163), WC's (UEs.103 e 110) canos (UEs.111, 112, 117 e 140), pinturas e rebocos (UEs.004, 085, 100, 101 e 106), pavimentos (UEs.006, 005, 164 e 007) e chaminé (UEs.115, 119 e 123). É nesta fase que se integra o funcionamento da Casa de Pasto 'Grulha'.

A Fase VIII corresponde a uma segunda remodelação do interior do edifício, especialmente manifesta no piso 
térreo e datável da segunda metade do século XX. Caracterizou-se por um conjunto de repavimentações (UEs.005, 006 e 024) e revestimentos de paredes em azulejo (UEs.019, 020 e 021), bem como por amarrações de pisos sobradados (UEs.120 e 108). Nesta fase integraram-se também os vestígios correlacionados com o prédio n. ${ }^{0} 97$, nomeadamente a chaminé do terceiro piso (UE.139) e revestimentos/rebocos de paredes (UEs.156, 157, 158 e 159).

A Fase IX corresponde ao incêndio que em 2006 destruiu completamente o edifício, aparecendo representada no alçado por diversas manchas de calcinação de cor negra, que resultaram da combustão das diversas estruturas de madeira (UEs.088, 093, 102, 107, 109 e 161).

Em 2007 o edifício foi demolido (Fase X), registandose no alçado da Torre as diversas interfaces de ruptura de paredes, telhado, WC's, chaminé (UEs.087, 092, 105, $113,116,118,154$ e 200).

Em síntese, confirmou-se que o alçado poente da torre medieval da Porta Nova conservava os vestígios dos edifícios que aí se foram adossando, tendo-se conseguido, com a leitura estratigráfica, compreender a evolução arquitectónica correspondente. Constatou-se, assim, que o alçado, no seu estado actual, é um repositório da sucessão construtiva aí realizada entre os séculos XV e XXI, constituindo um dos mais importantes exemplos, porque único no género, da história da edificação urbana da cidade de Braga.

Consequentemente, recomendou-se:

a) A escavação arqueológica integral da área de cave prevista no projecto, se o promotor da obra decidisse manter essa opção. Nesse caso, admitiu-se que, exceptuando o achado de qualquer vestígio de características excepcionais, a vulgaridade e reduzido valor dos vestígios já identificados e outros similares, não justificariam a sua conservação, pelo que poderiam ser desmontados, viabilizando-se a construção da cave, de acordo com os legítimos interesses do promotor da obra.

b) A conservação do alçado da torre medieval com todos os vestígios das construçôes posteriores, de modo a que, qual palimpsesto do urbanismo desta zona da cidade, possa ser observado por visitantes interessados e por estudiosos, naturalmente condicionados pela circunstância de se tratar de propriedade privada. Neste sentido, foi proposta uma simples remoção das herbáceas que crescem espontaneamente nas juntas dos cilhares, uma lavagem simples da parede, com água destilada, sem pressão e eventual 'tomada' de juntas, com argamassas tradicionais (sem cimento tipo portland) c) A conservação e integração no novo edifício, da bica e tanque de água colocado a descoberto na parte inferior da torre medieval, em qualquer das soluçôes construtivas que viesse a ser aprovada, a qual deve sempre garantir um afastamento mínimo de $1,20 \mathrm{~m}$ da fachada $\mathrm{da}$ referida torre.

\subsubsection{A Praça Velha}

A área de estudo abarca uma pequena zona delimitada a Este pela Rua D. Frei Caetano Brandão, a Norte pelo troço terminal da Rua D. Diogo de Sousa, a Oeste pelo Arco da Porta Nova e lado poente da Praça Velha, e a Sul pela Rua da Praça Velha (2.2.3 da Fig.2), e foi objecto de um ensaio de registo e análise das arquitecturas e morfologia urbana, numa perspectiva de previsão de impactes e correspondentes medidas de minimização, realizado no

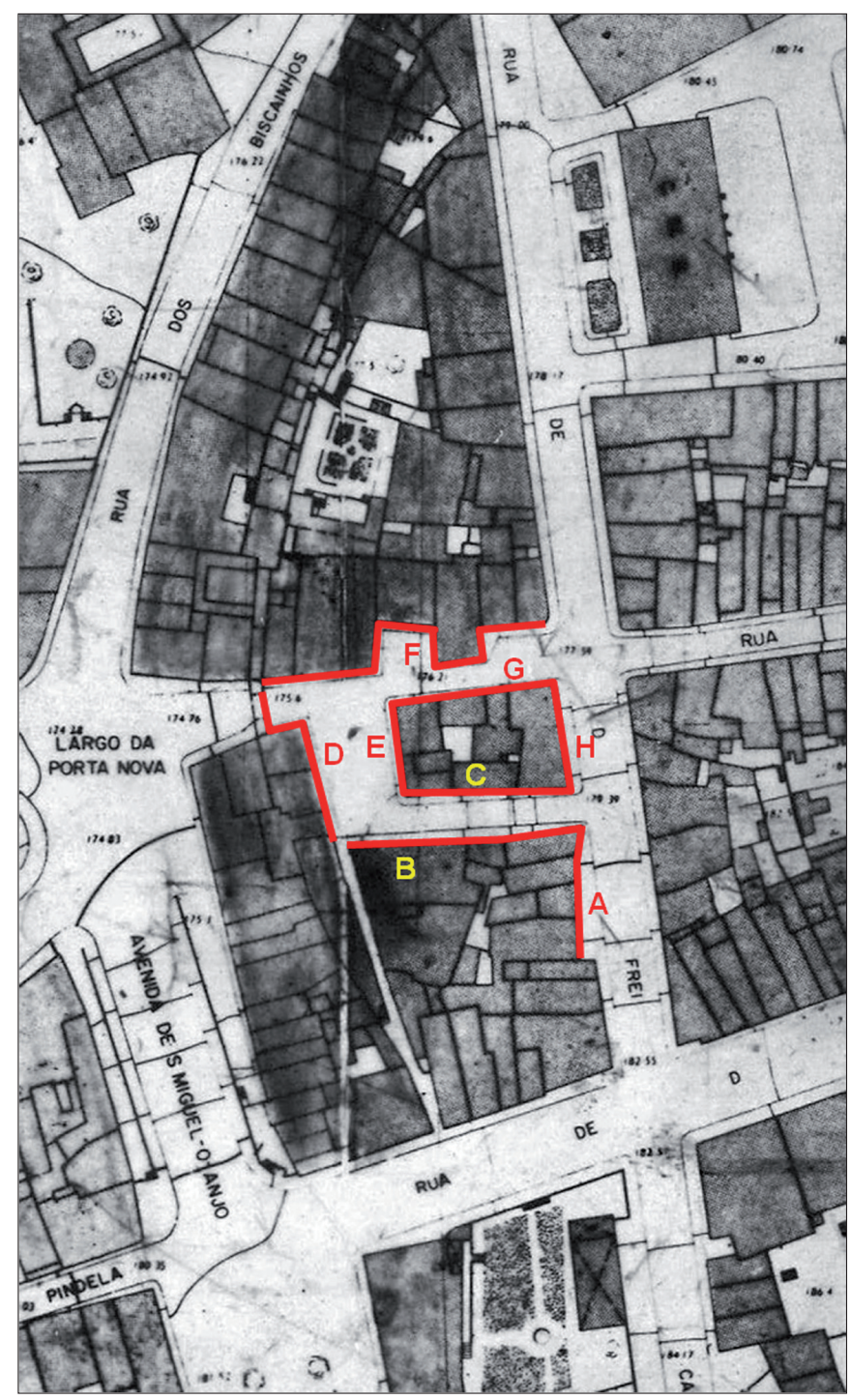

Fig. 13. Localização da área de estudo na planta de Braga, com identificação dos conjuntos de alçados 
âmbito do Seminário I - Arqueologia da Arquitectura, integrada no plano curricular de 2008/2010 do Mestrado em Arqueologia da Universidade do Minho.

\section{Morfologia urbana e arquitecturas}

Esta zona apresenta como elemento central a designada Praça Velha, que foi em tempos um nó urbanístico fundamental, idealizado pela visão pragmática do Arcebispo D. Diogo de Sousa, que o integrou numa das principais artérias de entrada e saída da cidade de Braga, funcionando como ponto de abastecimento e comércio.

A par da abertura da Rua de Sousa e da Porta de Sousa, nos inícios do séc. XVI, o Arcebispo D. Diogo de Sousa mandou fazer, junto da nova entrada, uma fonte e, defronte desta, uma praça, na qual ordenou a instalação de um mercado de peixe (Costa 1993: 112-113).
A fundação da Praça do Pescado, junto da nova Porta de Sousa, insere-se num vasto plano de ordenamento urbano, racionalizado, fixando um novo eixo de circulação que atravessou a cidade no sentido Este/Oeste, alinhando a então nova Rua de Sousa com a antiga Rua do Souto. É este eixo que se afirma como espinha dorsal da cidade, articulando a cidade alto medieval, a Sul, herdeira da malha urbana romana, com a cidade tardo medieval, a Norte, ordenada pelo castelo e pelo paço episcopal, construídos nos inícios do século XIV.

Elemento estrutural de maior relevo deste espaço, a nova Porta de Sousa foi aberta na muralha tardo medieval, junto de uma das suas torres, em 1512. Em 1772 viria a ser monumentalizada, por iniciativa do Arcebispo D. Gaspar de Bragança, designando-se desde então por Arco da Porta Nova.
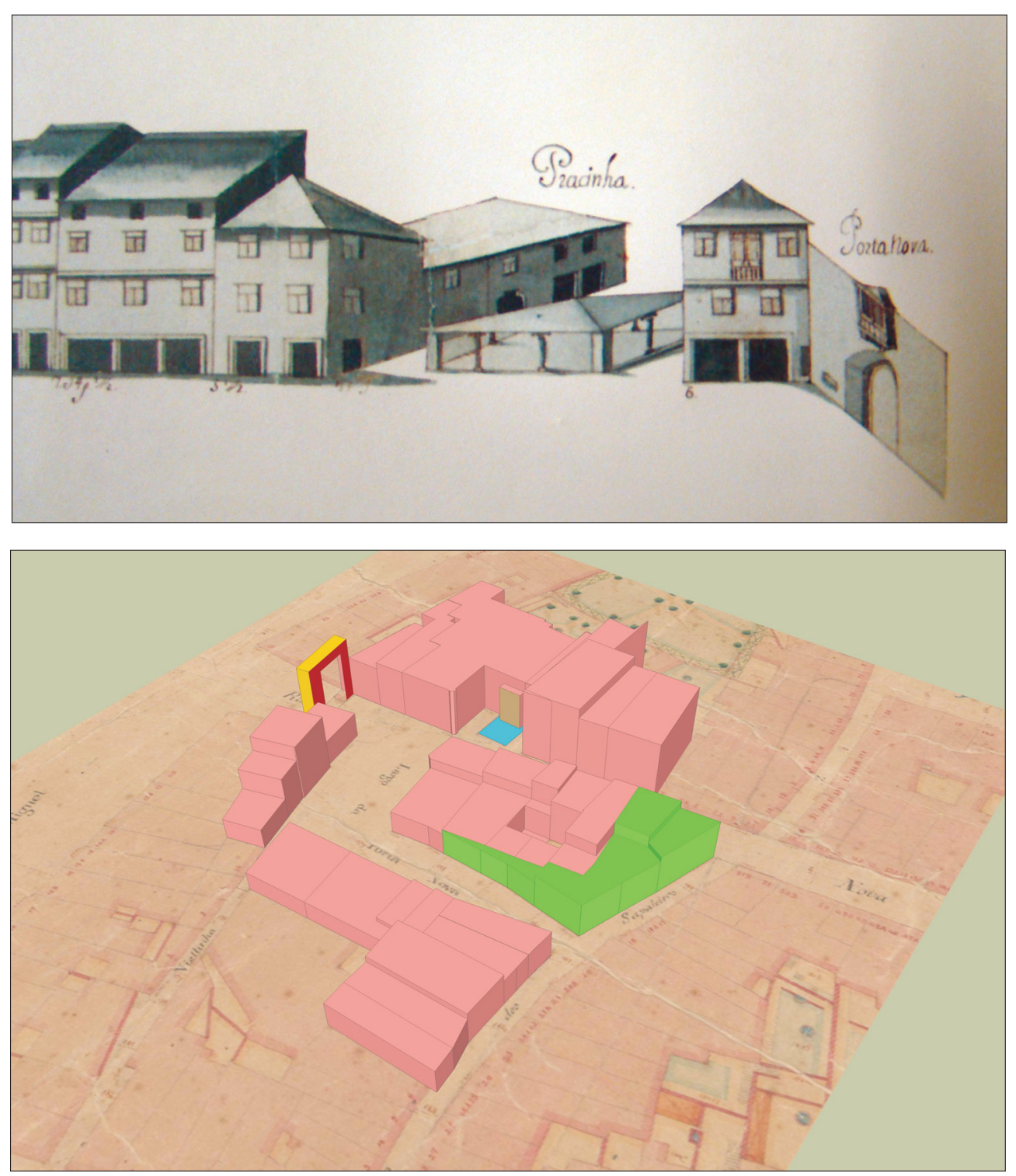

Fig.14. Representação da Praça Velha no Mappa das Ruas de Braga, 1750
Fig. 15. Projecção volumétrica das edificações em torno da Praça Velha, distinguindo-se, a cor verde, o edificado desaparecido com a abertura da Rua D. Frei Caetano Brandão, c. 1890 
Da análise efectuada sobressai, desde logo e apesar das evidentes transformações ao nível dos estilos arquitectónicos dos edifícios e da própria conformação dos lotes, que a praça, enquanto espaço aberto, poucas alterações conheceu desde a sua implantação, nos inícios do século XVI.

Entre as alteraçōes mais significativas regista-se a demolição do alpendre do mercado, em 1769, e o avanço do espaço privado para a área pública no recanto da Fonte de Sousa, com o edifício a ocupar o terreiro do fontanário, absorvendo-o e eliminando o usufruto público do mesmo. Temos portanto um espaço que, apesar das pequenas alterações que sofreu, se manteve na malha urbana, fossilizando as opçōes tomadas por D. Diogo de Sousa.

Mais significativa foi a alteração do topo nascente da área de estudo, determinada pela abertura da Rua D. Frei Caetano Brandão, nos finais do século XIX (Oliveira 1982:39). De facto, a sobreposição deste eixo às anteriores Ruas dos Çapateiros e Verde, alterou definitivamente o eixo modulador anterior e, como consequência, o loteamento e as fachadas. Aparentemente sobreviventes desta transformação, os quatro edifícios a Sul do cruzamento com a Rua da Praça Velha apresentam ainda a traça do arruamento anterior, a Rua Verde, conservando as suas fachadas um elevado número de elementos arquitectónicos que reportam, pelo menos, ao séc. XVI (Maurício 2000: 112).

Quando atentamos no loteamento, cujos levantamentos mais fidedignos se revelam no Mappa das Ruas de Braga (sem escala definida mas com indicação das medidas dos lotes) e o detalhado conjunto cartográfico levantado por Goullard, constata-se que as mudanças mais expressivas foram as provocadas pela abertura da Rua D. Frei Caetano Brandão, que suprimiu todo o topo Este dos Conjuntos F, G e H.

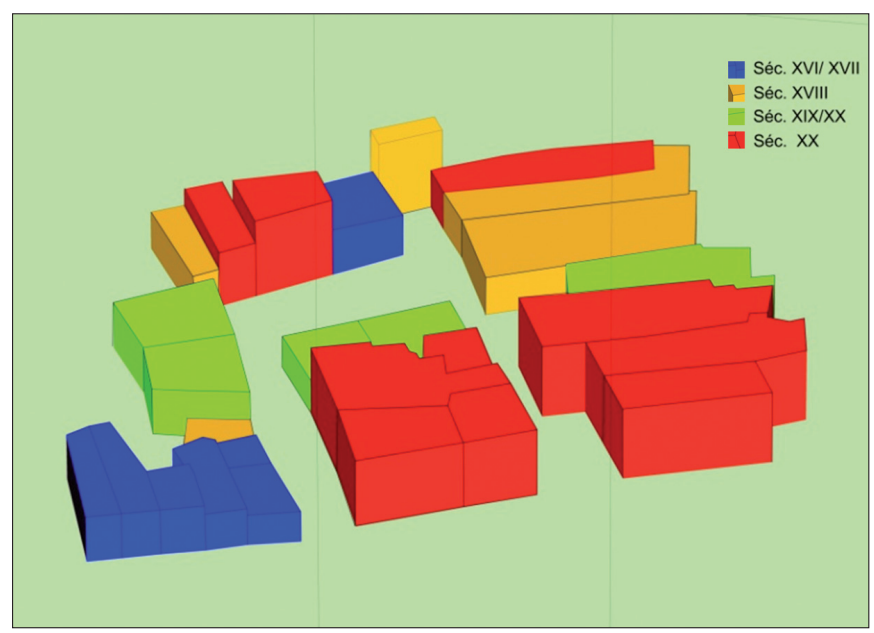

Fig. 16. Representação esquemática da cronologia das edificações em torno da Praça Velha
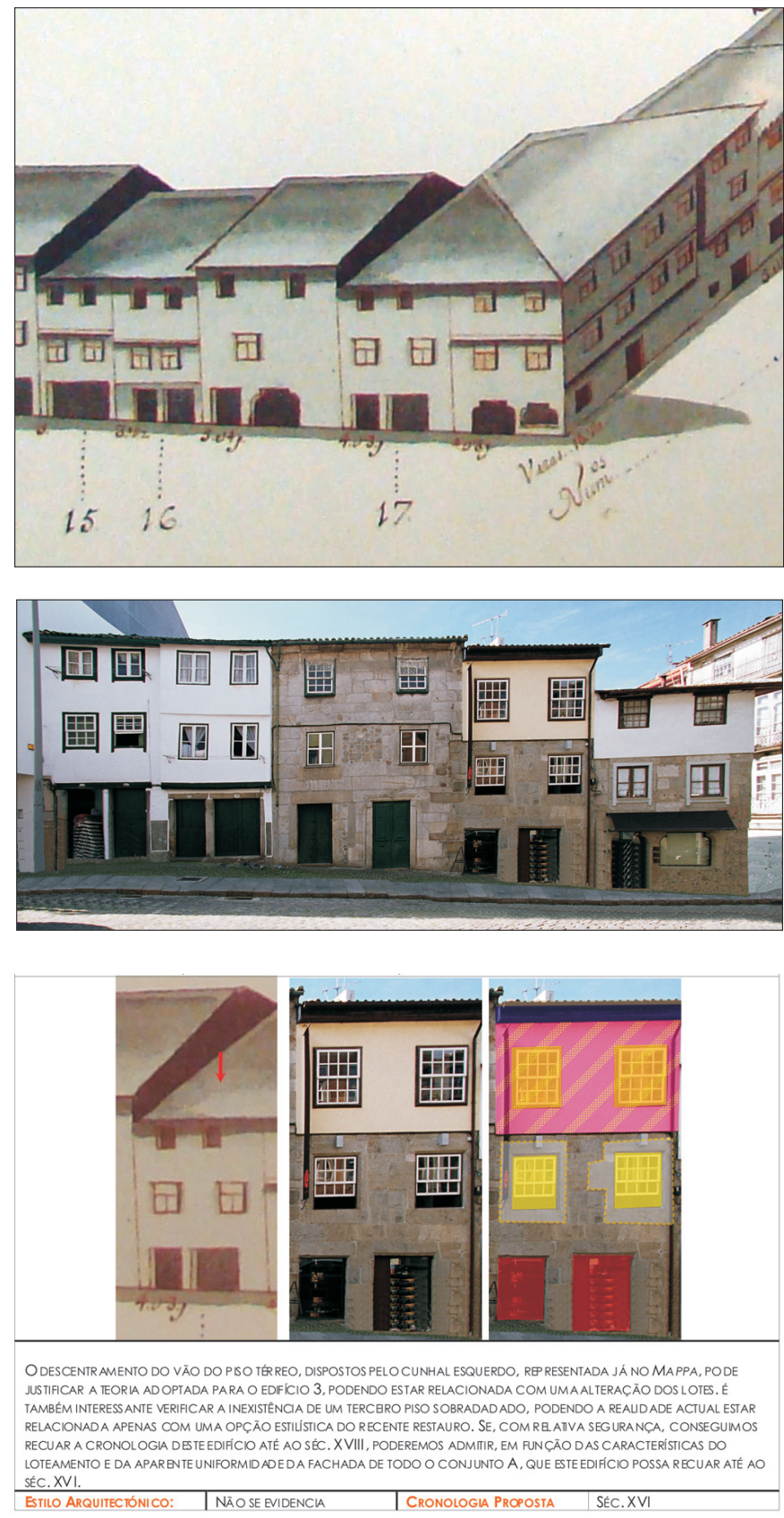

Fig. 17. Registo e caracterização das fachadas do Conjunto $\mathrm{A}$

No quarteirão central, formado pelos conjuntos C, E, $\mathrm{G}$ e $\mathrm{H}$, podemos perceber a mutação do micro loteamento original, para um loteamento de empreendimento actual, que procedeu à aglutinação entre lotes dentro do quarteirão, de forma a melhor responder às necessidades actuais de espaço que, contudo, desvirtuam completamente a matriz funcional anterior. $\mathrm{O}$ mesmo se verifica no topo nascente do alçado norte da Rua D. Diogo de Sousa, onde, por via da abertura da Rua D. Frei Caetano Brandão, se verificou o recuo da linha de fachada, compensada com aumento do número de pisos por edifício. 

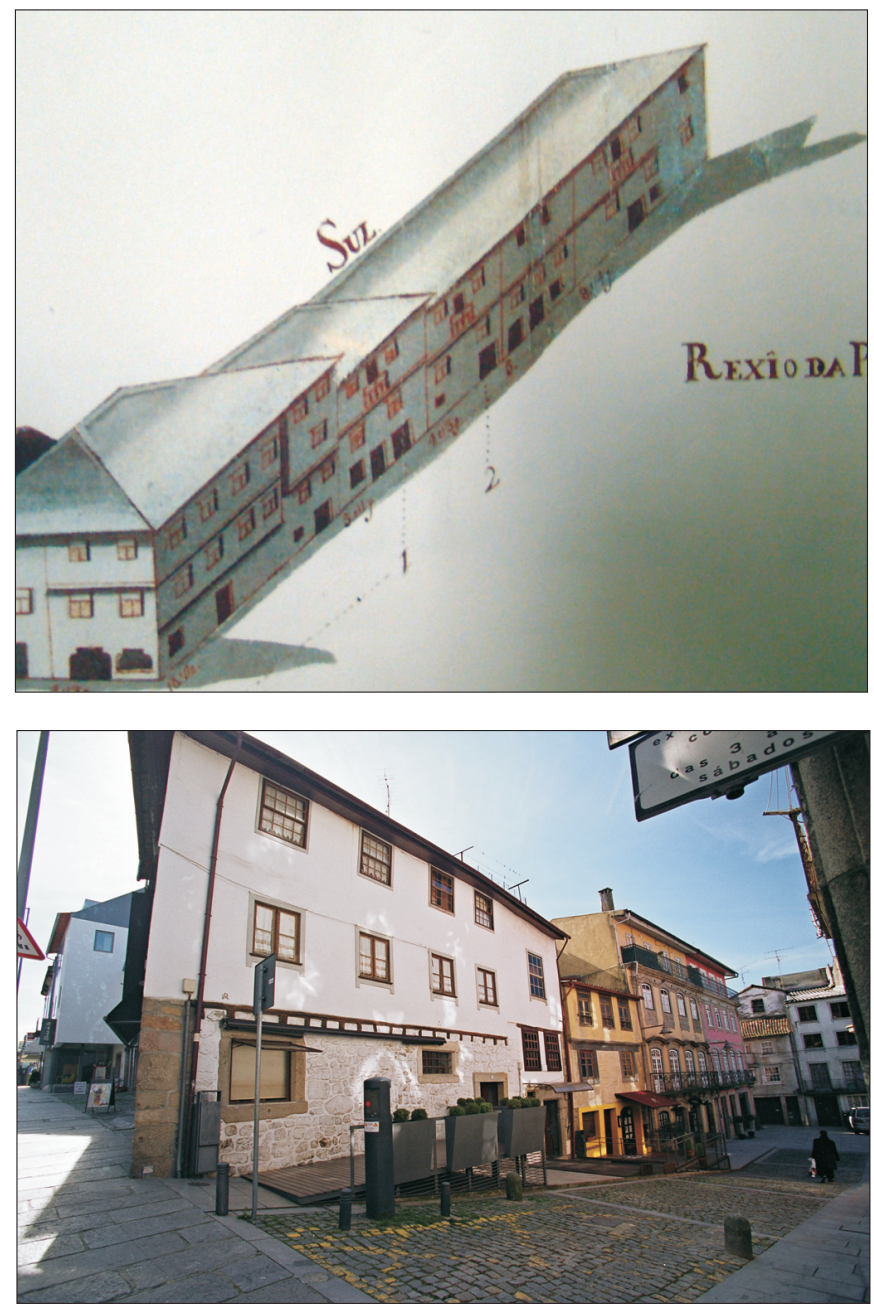

Fig. 18. Registo e caracterização das fachadas do Conjunto B

A análise das fachadas revela, nos seus distintos desenhos arquitectónicos, variações concordantes com as alteraçóes registadas nos loteamentos, expressando uma dinâmica reconstrutiva da cidade em que domina a sobreposição e substituição, proporcionando um verdadeiro mostruário de soluções construtivas e de estilos arquitectónicos. Para apresentação neste artigo, seleccionamos apenas quatro conjuntos de fachadas, ilustrativos das referidas variaçōes e diferentes soluções arquitectónicas.

Os cinco edifícios correspondentes ao Conjunto A, na rua D. Frei Caetano Brandão, representam o conjunto de edificaçōes mais antigas, sendo os únicos que conservam

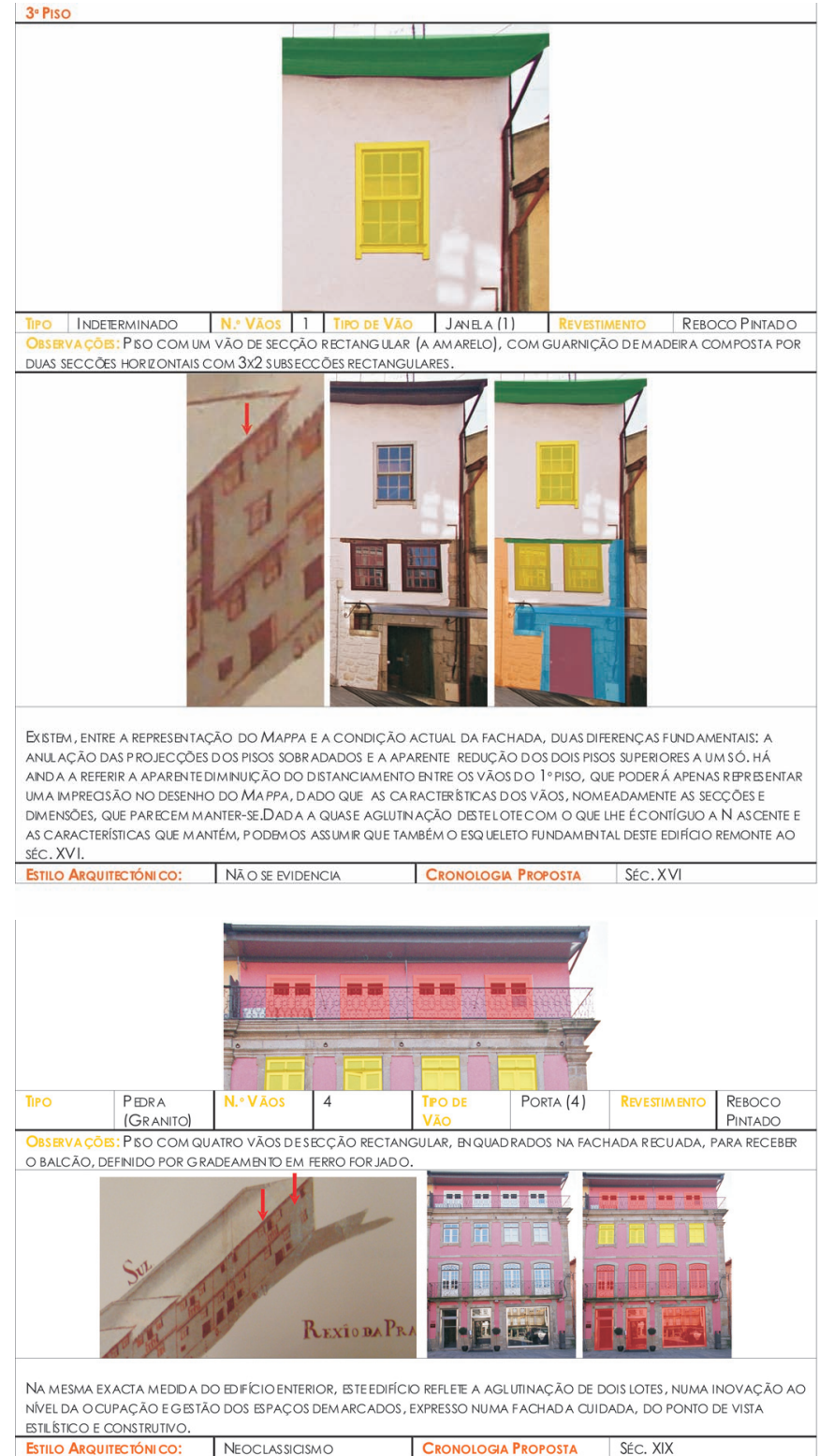

elementos arquitectónicos e modulação característicos do século XVI. Mantiveram-se, com poucas alteraçôes, desde pelo menos o séc. XVIII, dado que as fachadas actualmente visíveis são concomitantes com a representação do Mappa das Ruas de Braga.

O Conjunto B é composto pela fachada sul da Rua da Praça Velha. Actualmente, apresenta cinco edifícios, mas à data da realização do Mappa apresentava sete, sendo evidente a aglutinação dos quatro lotes a poente da rua, divididos em dois lotes de iguais dimensões, em relação à fachada. A divergência do ângulo das fachadas a partir do edifício três pode estar relacionada com esta alteração do loteamento. 

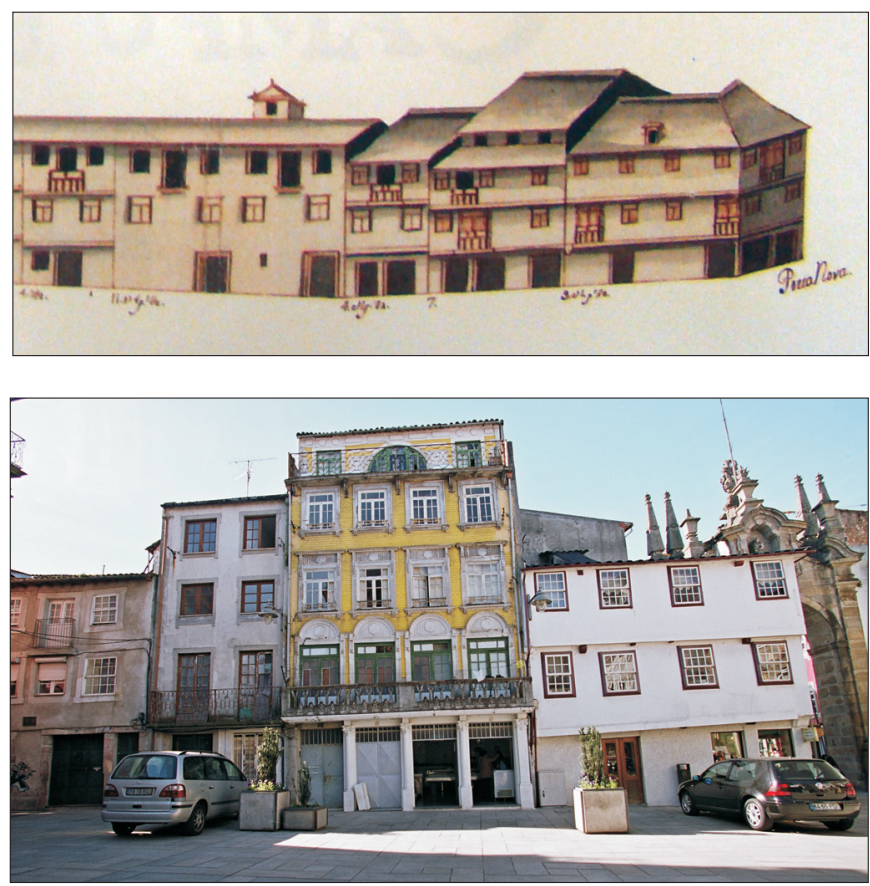

Fig. 19. Registo e caracterização das fachadas do Conjunto D

Para além de edifícios que conservam soluções construtivas de tradição medieval, identificam-se neste conjunto edificações do século XIX, de expressão estilística neoclássica, reveladora da adopção, no casco antigo da cidade, dos novos modelos construtivos que caracterizam uma das fases de expansão do tecido urbano bracarense, especialmente manifesta fora do perímetro medieval da cidade.

$\mathrm{O}$ conjunto $\mathrm{D}$ corresponde à fachada oeste da Praça Velha. Aparentemente preserva o loteamento desenhado no Mappa, mas percebem-se profundas diferenças ao nível das fachadas, especialmente manifestas nas fachadas três e

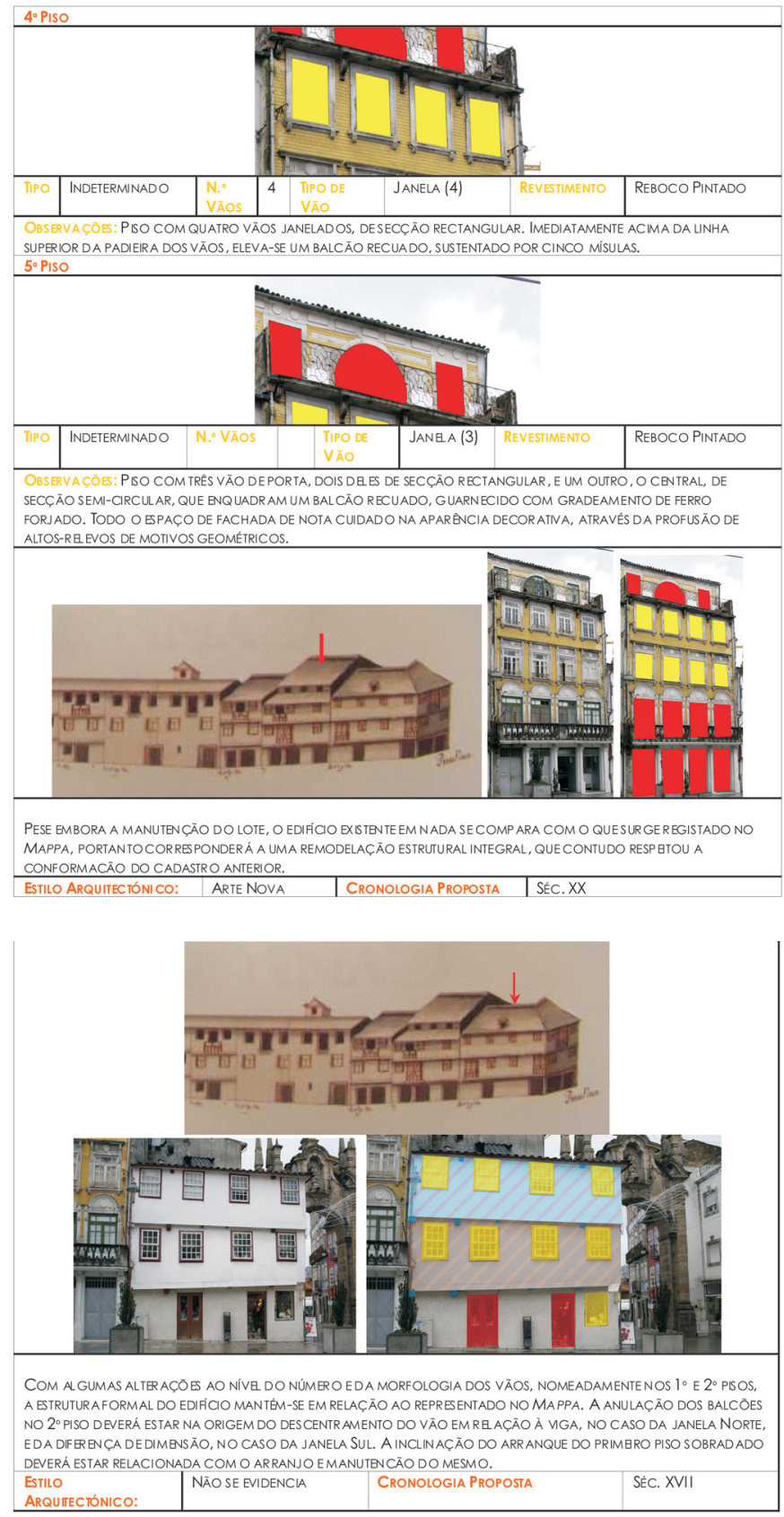

quatro, a primeira testemunhando a renovação construtiva do século XIX, aqui numa expressão estilística vinculada à "Arte Nova» e a segunda a permanência da construção original do lote, datável dos séculos XVI-XVII.

Finalmente, o conjunto $\mathrm{F}$, que agrupa os edifícios que formam a fachada norte da Rua D. Diogo de Sousa, desde o Arco da Porta Nova até ao cruzamento com a Rua D. Frei Caetano Brandão. Para além da renovação construtiva dos lotes junto ao arco, muito provavelmente na sequência da sua monumentalização no século XVIII, são notórias as diferenças a partir do lote recuado do conjunto (coinciden- 

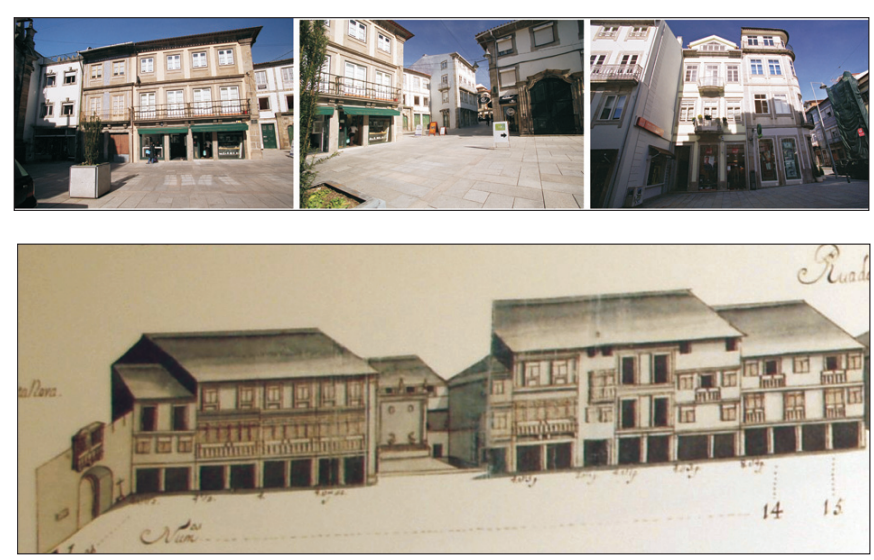

Fig. 20. Registo e caracterização das fachadas do Conjunto F

te com a implantação da fonte de Sousa), as quais testemunham as alteraçóes impostas pela abertura da Rua D. Frei Caetano Brandão nos finais do século XIX.

\section{Avaliação de impactes e medidas de minimização}

Uma cidade viva é uma entidade dinâmica, que se renova em permanência, com ritmos e intensidades diversas, resultantes da complexa actuação de forças sociais, económicas e culturais, externas e internas.
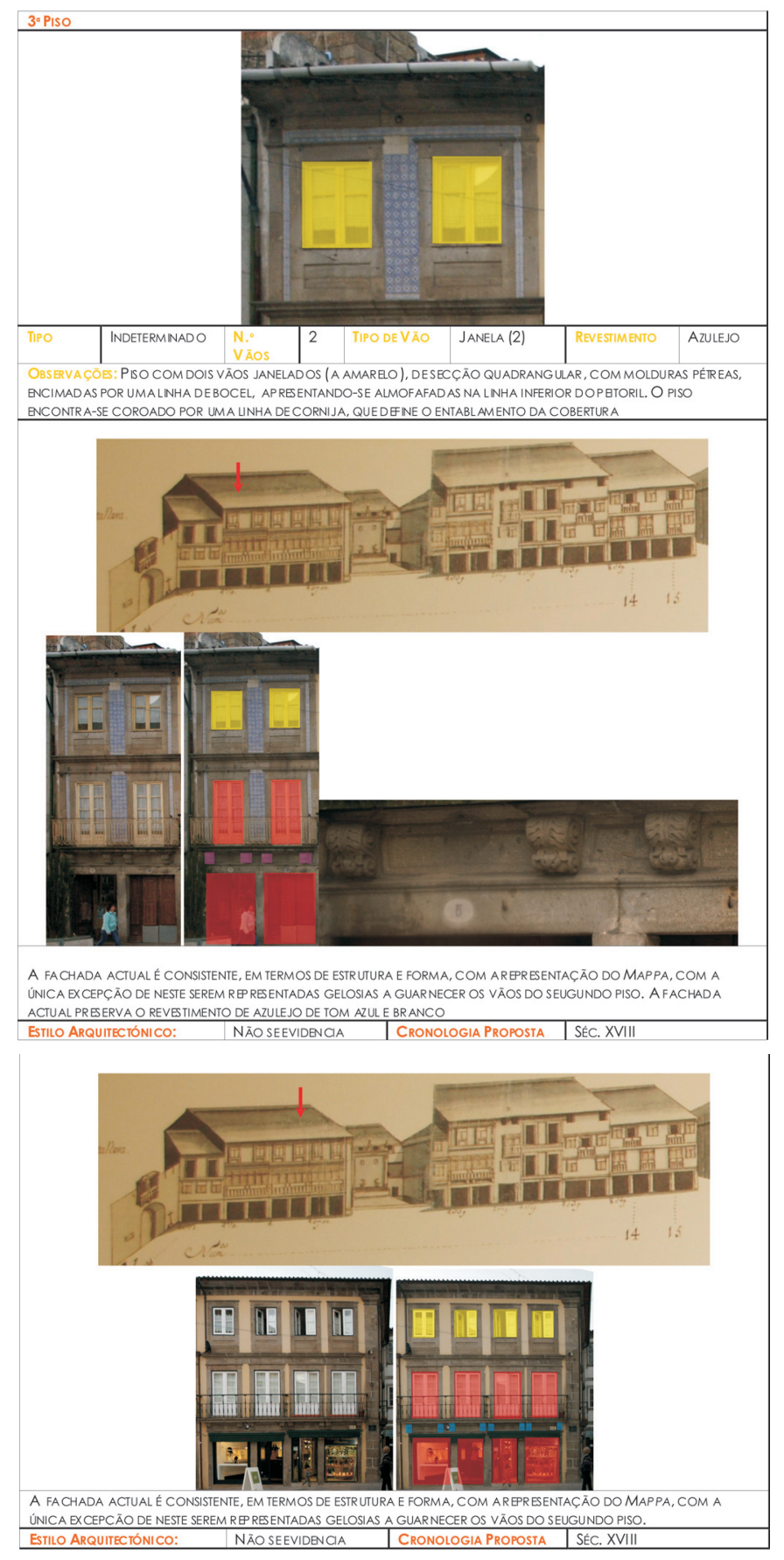

Assim é Braga, fundada há mais de 2000 anos e que conserva ainda importantes testemunhos da sua evolução no tempo longo, ilustrando a transformação histórica da sociedade e das relações estabelecidas com o meio envolvente. O edificado traduz essa evolução histórica, constituindo a expressão física da vida urbana, mais ou menos cosmopolita, que se manifesta nas variaçôes estilísticas das fachadas e nas soluções construtivas.

A cidade é um local de permanência e simultanea- 
mente de passagem, onde o uso e a exploração são, por si só, causadores de impacte. A cidade é também um espaço público, com gestão própria, cujas necessidades de crescimento, manutenção, melhoramento e renovação são muitas vezes feitas a expensas do edificado histórico. Mas a cidade é fundamentalmente um sítio onde coabitam vontades individuais, pouco esclarecidas muitas vezes acerca da necessidade da compreensão do casco histórico, que intervêm directamente sobre o edificado, alterando-o sem que dessa alteração fique registo.

É portanto previsível a ocorrência de impactes sobre a área de estudo considerada, ou melhor, sobre ela ocorrem impactes decorrentes tão-somente da apropriação e uso dos seus espaços. Importa, pois, perceber esta ocorrência, saber avaliar-lhe a escala, para prevenir alteraçóes da sua estrutura histórica ou, pelo menos, para registar o existen- te, até porque são já vários os imóveis completamente reconstruídos, que anularam as características construtivas e funcionais do edificado anterior, sem que se tenha efectuado qualquer registo e estudo metodologicamente orientado pelos procedimentos fixados pela Arqueologia da Arquitectura.

Para ensaiar a elaboração de uma proposta de avaliação de impactes e correspondentes medidas de minimização, admitiu-se a existência de riscos previsíveis sobre o património da área de estudo, por impacte directo (obras, remodelações, agentes naturais) ou indirecto (uso).

Para o efeito, consideraram-se como fundamentais um conjunto de variáveis pré-definidas, no sentido de realizar uma análise em termos qualitativos (impacte positivo ou negativo) e quantitativos (grau de significância) e, desse modo, estabelecer uma hierarquia (ver Quadro abaixo).

\begin{tabular}{|c|c|c|c|c|}
\hline 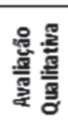 & Natureza & $\begin{array}{l}\text { Positivo } \\
\text { Negativo }\end{array}$ & $\begin{array}{l}\mathrm{P} \\
\mathrm{N}\end{array}$ & $\begin{array}{l}\text { Se o impacte produz efeitos que promovem a qualidade } \\
\text { do património edificado } \\
\text { Se o impacte produz efeitos que reduzem a qualidade do } \\
\text { património edificado }\end{array}$ \\
\hline \multirow{6}{*}{ 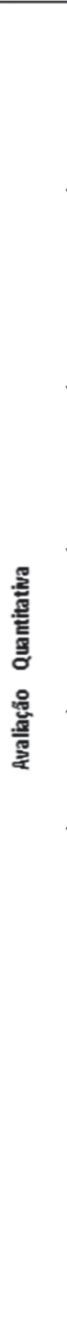 } & Escala (E) & $\begin{array}{l}\text { In situ } \\
\text { Local } \\
\text { Regional }\end{array}$ & $\begin{array}{l}1 \\
3\end{array}$ & $\begin{array}{l}\text { Com capacidade de alterar o contexto apenas na área de } \\
\text { contacto } \\
\text { Com capacidade para alterar o contexto ao nivel da } \\
\text { localidade } \\
\text { Com capacidade de alterar o contexto para além da } \\
\text { localidade }\end{array}$ \\
\hline & Duração (D) & $\begin{array}{l}\text { Nulo } \\
\text { Temporário } \\
\text { Permanente }\end{array}$ & $\begin{array}{l}1 \\
3 \\
5\end{array}$ & $\begin{array}{l}\text { Raramente ocorre ao longo das fases do projecto } \\
\text { (períodos contínuos inferiores a } 1 \text { dia) } \\
\text { Pode ocorrer ao longo das fases do projecto (periodos } \\
\text { contínuos superiores a } 1 \text { dia) } \\
\text { Ocorre continuamente durante a implementaçãoe } \\
\text { exploração do projecto }\end{array}$ \\
\hline & Reversibilidade (R) & $\begin{array}{l}\text { Nulo } \\
\text { Reversivel } \\
\text { Irreversivel }\end{array}$ & $\begin{array}{l}1 \\
3 \\
5\end{array}$ & $\begin{array}{l}\text { O impacte é residual ou nulo } \\
\text { Existe impacte em uma ou mais vertentes do património, } \\
\text { mas este oferece possibilidades de recuperação } \\
\text { Existe impacte em uma ou mais vertentes do património, } \\
\text { sem possibilidades de recuperação }\end{array}$ \\
\hline & $\begin{array}{l}\text { Probabilidade } \\
\text { Ocorrência (PO) }\end{array}$ & $\begin{array}{l}\text { Improvável } \\
\text { Provável } \\
\text { Certo }\end{array}$ & $\begin{array}{l}1 \\
3 \\
5\end{array}$ & $\begin{array}{l}\text { A probabilidade de ocorrência de impacte é baixa ou nula } \\
\text { Se a ocorrência do impacte estiver baseada em factos } \\
\text { subjectivos e/ou não quantificáveis } \\
\text { Se for possível quantificar objectivamente a alteração que } \\
\text { ocorrerá no património }\end{array}$ \\
\hline & Significância (S) & $\begin{array}{l}\text { Pouco Significativo } \\
\text { Significativo } \\
\text { Muito Significativo }\end{array}$ & $\begin{array}{c}\{1,27\} \\
\{27,225\} \\
\{225,625\}\end{array}$ & $S=E \times D \times R \times P O$ \\
\hline & $\begin{array}{l}\text { Valor Patrimonial } \\
\text { (VP) }\end{array}$ & $\begin{array}{c}\text { Nulo } \\
\text { Baixo } \\
\text { Médio-Baixo } \\
\text { Médio } \\
\text { Médio-Elevado } \\
\text { Elevado }\end{array}$ & ○ & $\begin{array}{l}\text { Elemento desprovido de valor patrimonial } \\
\text { Elemento comum, de cronologia recente, sem } \\
\text { caracteristicas que o destaquem na leitura patrimonial do } \\
\text { seu contexto histórico } \\
\text { Elemento comum, de cronologia recente, com algumas } \\
\text { caracteristicas que o destaquem na leitura patrimonial do } \\
\text { seu contexto histórico } \\
\text { Elemento comum, representativo de um período } \\
\text { histórico, com características individuais que se destacam } \\
\text { na leitura patrimonial do seu contexto histórico } \\
\text { Elemento representativo de um período histórico, com } \\
\text { bastantes características individuais que se destacam na } \\
\text { leitura patrimonial do seu contexto histórico } \\
\text { Elemento de elevada importância, representativo de um } \\
\text { período histórico, cujas características individuais são } \\
\text { importantes para a leitura patrimonial do seu contexto } \\
\text { histórico }\end{array}$ \\
\hline
\end{tabular}

Fig. 21. Proposta de critérios para avaliação de impactes 
Para efeitos deste ensaio consideraram-se apenas três tipos de impactes: o impacte associado à actuação dos serviços públicos; o impacte decorrente da actuação dos privados; e os impactes relacionados com os riscos de incêndio e sísmico.

Ao sector público compete, de modo directo ou indirecto, a gestão dos espaços urbanos, constituindo as redes de infra-estruturas básicas urbanas uma das suas maiores responsabilidades. Os projectos associados à construção e manutenção das redes de saneamento, água, electricidade, gás e comunicaçôes são, como tal, causadores de impactes no subsolo, a par da repavimentação das vias e da modelação do mobiliário urbano, entre tantas outras actuaçóes potencialmente causadoras de impacte.

Mas a intervenção dos promotores privados é, sem dúvida, aquela que maior impacte provoca no edificado histórico. As obras de remodelação, não raras vezes verdadeiras reconstruções, sem qualquer registo ou estudo dos modelos anteriores, alteram o existente e anulam a percepção da evolução dos conjuntos construídos, desprovidos das suas características formais e funcionais originais, sem que exista qualquer acção de minimização em momento prévio ao da execução dos projectos.
Por sua vez, considerando as características da construção tradicional identificada, em que dominam pisos superiores sobradados, divisórias em tabique e estruturas de cobertura em madeira, facilmente inflamáveis e estruturalmente mais frágeis, justificar-se-á a criação de um plano de pormenor de risco para o edificado histórico, onde possam ser equacionados os riscos reais de incêndio e, secundariamente, de impacte sísmico e criados mecanismos de resposta rápida à ocorrência de qualquer um destes factores.

Admitida a existência de impactes e riscos, importa estabelecer medidas que permitam a sua minimização. Salvaguardando a questão importante da actuação articulada de diferentes especialidades nas intervençôes em cidades históricas, como estabelecem, aliás, as recomendações internacionais, reconhece-se à arqueologia um papel fundamental, devendo os arqueólogos providenciar toda a informação necessária às autoridades da tutela e aos promotores, o mais antecipadamente possível.

Nesta perspectiva, qualquer projecto que se reconheça de impacte sobre o edificado histórico deverá ser objecto de uma avaliação rigorosa e contemplar, entre outras, as medidas de minimização descritas no quadro abaixo.

\begin{tabular}{|c|c|}
\hline Acompanhamento Arqueológico & $\begin{array}{l}\text { Consiste na observação, feita por um arqueólogo, das operações que impliquem impacte sobre qualquer parte do } \\
\text { edificado em si, ou do subsolo adjacente. Este procedimento deve ser alvo de registo fotográfico, gráfico e descritivo, em } \\
\text { registo normalizado. Os resultados do acompanhamento arqueológico podem determinar a adopção de medidas de } \\
\text { minimização extraordinárias (sondagens parietais, sondagens no solo, registo pormenorizado, etc.). Os achados móveis } \\
\text { efectuados no decurso destas aç̧ões devem ser colocados em depósito credenciado pelo organismo de tutela } \\
\text { competente. }\end{array}$ \\
\hline Conservação & $\begin{array}{l}\text { Durante o acompanhamento arqueológico deve ser promovida a conservação in situ das ocorrências às quais seja } \\
\text { reconhecido inegável valor patrimonial, no conjunto do edificado, salvo impossibilidade estrutural e operacional no } \\
\text { contexto do seguimento das acções de impacte. }\end{array}$ \\
\hline Sondagens Arqueológicas & $\begin{array}{l}\text { Esta medida refere-se à realização de sondagens parietais ou no solo, determinantes para a compreensão do edificado, } \\
\text { destinadas a obter informação sobre a as ocupações e funcionalidades do edifício/ conjunto edificado. As sondagens } \\
\text { deverão ser realizadas em função da pertinência do estudo científico em que se enquadrem e sempre em articulação com } \\
\text { a compreensão diacrónica do espaço e da sua relação com a envolvente. }\end{array}$ \\
\hline Prospecção Arquitectónica & $\begin{array}{l}\text { Deve ser desenhada caso a caso, tendo em atenção a questão da visibilidade/invisibilidade aparente. No caso da análise } \\
\text { das fachadas, o edificado deve ser entendido como um conjunto de módulos que apontam para a sua compreensão. } \\
\text { Deve complementar não só as evidências físicas, ou seja, o edificado, mas também as documentais, que podem comportar } \\
\text { dados importantíssimos para ajudar o investigador na identificação das diferentes fases do edifício/ conjunto edificado. }\end{array}$ \\
\hline Registo & $\begin{array}{l}\text { Esta acção consiste na representação gráfica, fotográfica e documental que, reunida sob a forma de relatório ou de } \\
\text { memória descritiva, revele todas as acç̃̃es que causaram impacte sobre o edificado existente, e que as posicione, } \\
\text { rigorosamente, no contexto físico do edifício /conjunto edificado. }\end{array}$ \\
\hline Valorização & $\begin{array}{l}\text { A valorização patrimonial deve ser pensada caso a caso, devendo ser desenvolvidas um conjunto de medidas relacionadas } \\
\text { com o estudo, a fruição pública e a conservação activa dos elementos a preservar. }\end{array}$ \\
\hline
\end{tabular}

Fig. 22. Conceitos associados às medidas de minimização 


\section{CONSIDERAÇÕES FINAIS}

Independentemente da diversidade quantitativa e qualitativa dos dados obtidos, decorrente da diferente estratégia e modalidade de actuação concretizadas, julgamos que os resultados proporcionados pelos três estudos apresentados, demonstram bem a importância da Arqueologia da Arquitectura no contexto do estudo das cidades históricas.

Efectivamente, com as intervenções preventivas na Rua dos Biscainhos, obtiveram-se dados que permitem caracterizar melhor as soluções construtivas da cerca medieval de Braga e das edificações que se sucederam em época moderna, conformando o quarteirão. Confirmou-se igualmente a estreita vinculação da evolução da malha urbana medieval às alteraçôes progressivas do seu sistema de fortificação, em que releva a expansão da cidade para Norte, ultrapassando o limite setentrional da cidade romana.

Com o estudo prévio da morfologia e arquitecturas da Praça Velha, obtiveram-se dados que expressam com clareza o processo de alteração dinâmica do tecido urbano bracarense, entre o século XVI e a actualidade. Pode afirmar-se que a Praça Velha e a envolvente próxima, constitui um dos mais importantes núcleos de arquitectura civil antiga da cidade de Braga, conservando um raro conjunto de edificações quinhentistas, de características formais únicas, que se articula com outras posteriores, numa expressão notável de quase cinco séculos de história do edificado.

Neste sentido, julgamos ter demonstrado a necessidade de reconhecer o estudo e a avaliação de impactes como uma técnica fundamental do planeamento urbano de uma cidade histórica, e que a Arqueologia da Arquitectura pode e deve, nessa matéria, dar um contributo significativo.

Finalmente, não queremos deixar de acentuar que, nas suas diferentes modalidades, de actuação preventiva e de ensaio académico, a estes três exemplos de Arqueologia da Arquitectura subjaz uma orientação basilar, a de produção de conhecimento, isto é, desenvolvimento de investigação. Investigação que, no contexto de actuação da chamada Arqueologia Urbana, só é frutuosa se enquadrada num projecto estruturado, continuado e cientificamente orientado de estudo, conservação e valorização, como o que é protagonizado pela Unidade de Arqueologia da Universidade do Minho em colaboração com o Município de Braga.

\section{REFERÊNCIAS BIBLIOGRÁFICAS}

Azkarate Galai-Olaun, A. (2008). La Arqueología de la Arquitectura en el siglo XXI. In Arqueología de la Arquitectura, 5. CSIC/UPV: Madrid/Vitoria, pp. 11-13.

Ballester J.M. (dir.) (2001). The Council of Europe and cultural heritage: $1954-$ 2000. Council of Europe Publishing: Strasbourg.

Benevolo, L. (1995). A Cidade na História da Europa. Editorial Presença: Lisboa. Caballero Zoreda, L. (2006). Arqueología de la Arquitectura. Conocimiento e intervención, in Património. Estudos, 9, Instituto Português do Património Arquitectónico: Lisboa, pp. 33-43.

Costa, A. (ed. crítica de) (1965) - Liber Fidei Sanctae Bracarensis Ecclesie, I, Junta Distrital de Braga: Braga.

Costa, A. (1993). D. Diogo de Sousa. Novo Fundador de Braga e grande Mecenas da Cultura, Braga.

Fontes, L. (1989). S. Frutuoso de Montélios, Comissão Regional Turismo Verde Minho: Braga.

Fontes, L. (2004). Roteiro Medieval de Braga, Câmara Municipal de Braga: Braga.

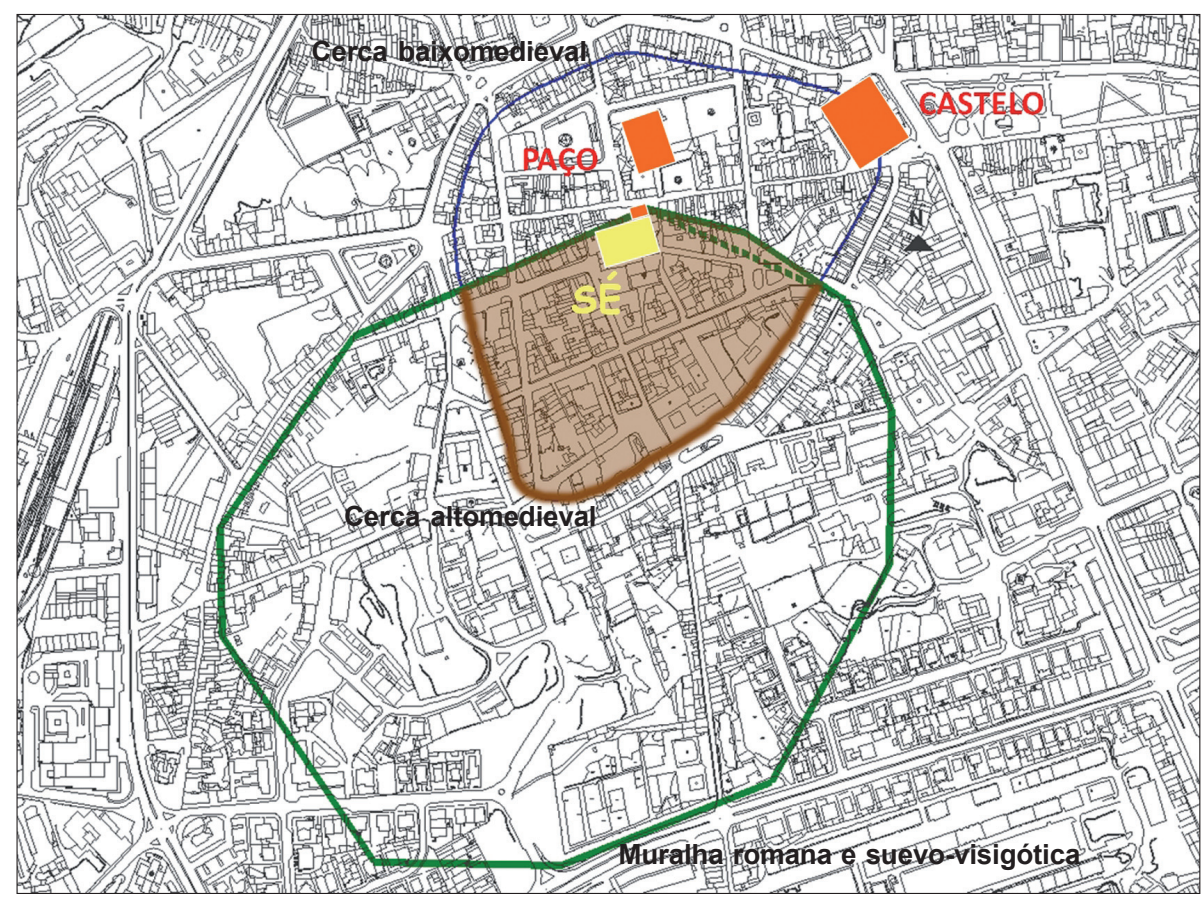


Fontes, L. (2006). A Basilica Sueva de Dume e o Túmulo dito de São Martinho, Narq: Braga.

Fontes, L. (2008) - A igreja sueva de São Martinho de Dume. Arquitectura cristã antiga de Braga e na Antiguidade Tardia do Noroeste de Portugal. Revista de História da Arte, 6, Actas do Ciclo de Palestras Internacional sobre «Arquitectura, Mosaicos e Sociedade da Antiguidade Tardia e Bizantina a Ocidente e Oriente. Estudos e Planos de Salvaguarda», FCG / UNL: Lisboa, p.162-181.

Fontes, L. (2009) - O Período Suévico e Visigótico e o Papel da Igreja na Organização do Território, in (coord. Paulo Pereira) Minho. Traços de Identidade, Conselho Cultural da Universidade do Minho: Braga, 2009, p.272-295.

Fontes, L., Lemos, F. e Cruz, M. (1997-98) - «Mais Velho» que a Sé de Braga. Intervenção Arqueológica na Catedral Bracarense: notícia preliminar, $C A$ DERNOS DE ARQUEOLOGIA, Série II, 14-15, UAUM/MDDS: Braga, pp. 137-164.

Groetelaars, N. e Amorim, A. (2004). Técnicas de restituição fotogramétricas digitais aplicadas à Arquitetura: um estudo de caso, in COBRAC 2004. Congresso Brasileiro de Cadastro Técnico Multifinalitário, UFSC: Florianópolis, p.1-12.

Mañana Borrazás, P., Blanco Rotea, R. e Ayán Vila, X. (2002). Arqueotectura 1: Bases teórico-metodológicas para una Arqueología de la Arquitectura. TAPA, 25. Laboratorio de Patrimonio, Paleoambiente e Paisaxe / IIT-USC: Santiago de Compostela.

Marques, J. (1986). O Castelo de Braga, MINIA, II. Aspa: Braga, p.5-34

Martins, M. (2004). Urbanismo e arquitectura em Bracara Augusta. Balanço dos contributos da Arqueologia Urbana, in Simulacra Romae. Roma y las capitales provinciales del Occidente Europeo. Estúdios arqueológicos, Tarragona, pp. 149174

Martins, M. (2010). A arqueologia urbana e a defesa do património das cidades, FORUM, 44-45 [2009-2010], Conselho Cultural da Universidade do Minho: Braga, (no prelo).

Martins M. e Fontes L. (2007-2008). Uma estratégia para o património bracarense: a criação de um Parque Cultural Europeu em Braga, in FORUM, 42-43, Universidade do Minho: Braga, p.255-286.

Martins, M e Fontes, L. (2010). Bracara Augusta. Balanço de 30 anos de investigação arqueológica na capital da Galécia romana, in Simulacra ROMAE II. Rome, les capitales de province (capita prouinciarum) et la création d'un espace commum européen. Une approche archéologique, (Reims, Novembro de 2008), Bulletin de la Societé archéologique champenoise, Mémoire n. 19, p.111-124.
Mateus, L. et alii (2008). A report on multiple approaches to the S. Frutuoso of Montélios Chapel Survey, in The 9th International Symposium on Virtual Reality, Archaeology and Cultural Heritage (VAST 2008), M. Ashley, S. Hermon, A. Proenca, and K. Rodriguez-Echavarria (Editors). pp. 1-8.

Maurício, R. (2000). O Mecenato de D. Diogo de Sousa, Arcebispo de Braga. Urbanismo e Arquitectura, 2 vols., Ed. Magno: Leiria.

MRB (1989/91). Mappa das Ruas de Braga, 2 vols., Arquivo Distrital de BragaUM e Companhia IBM Portuguesa: Braga.

Oliveira, E. (1982). Estudos bracarenses. As Alteraçōes Toponímicas (13801980). MVSEV, 3a Série, 1, Braga, p.5-121.

Ribeiro, M. (2008). Braga entre a época romana e a Idade Moderna. Uma metodologia de análise para a leitura da evolução da paisagem urbana. Universidade do Minho: Braga (Dissertaçāo de doutoramento policopiada).

Rodríguez Temiño, I. (2004). Arqueología urbana en España. Barcelona: Editorial Ariel.

VV.AA. (1986). I Encontro Nacional de Arqueologia Urbana (Setúbal, 1985), Ministério da Educação e Cultura / Secretaria de Estado da Cultura / Instituto Português do Património Cultural: Lisboa.

VV.AA (1994) Encontro de Arqueologia Urbana (Braga, 1994), Bracara Augusta, vol. XLV, n. 97 (110), Câmara Municipal de Braga: Braga.

VV.AA. (2002). $3^{\circ}$ Encontro de Arqueologia Urbana (Almada, 1997), Col. Monografias -Arqueologia, Câmara Municipal de Almada/DAS/DM: Almada.

VV.AA. (2004). Actas do IV Congresso de Arqueologia Peninsular, in Arqueologia de la Arquitectura, 3, CSIC/UPV: Madrid/Vitória.

VV.AA. (2006a). Património Arquitectónico. Registo, Interpretação e Critérios de Intervenção, in Património. Estudos, 9, Instituto Português do Património Arquitectónico: Lisboa.

VV.AA. (2009a). Actas do Simposio Internacional "Ciudad sobre ciudad. Interferencias entre pasado y presente urbano en Europa», Salamanca, 12-14 Noviembre 2008, Fundación del Patrimonio Histórico de Castilha y León: Valladolid.

VV.AA. (2009b). Arqueologia de la Arquitectura, 6, CSIC/UPV: Madrid/Vitória. VV.AA. (2010). Arqueologia, Patrimonio y Desarrollo Urbano. Problemática y Soluciones. Actas del Seminario de Girona, 3 de Julio de 2009, Ajuntament de Girona i Institut de Recerca Històrica de la Universitat de Girona: Girona.

Recibido: 5 de julio de 2010

Aceptado: 24 de octubre de 2010 